\title{
Effect of Acrylamide on Development of Cerebellum in Albino Rat
}

\section{Original Article}

\author{
Wesam E.S Amin, Ashraf S.Hegab, Amal Al Shahat Ibrahim and Hanan E.L. Mokhtar
}

Department of Anatomy and Embryology, Faculty of Medicine, Zagazig University, Egypt

\begin{abstract}
Introduction: Acrylamide (ACR) is a neurotoxic material to animals and humans.

Aim: To elucidate the possible structural changes that may occur in cerebellum of male albino rat offspring after oral administration of acrylamide to their pregnant and lactating mothers.

Material and Methods: After mating, 54 pregnant female rats were divided equally into three groups. Group A: did not receive any treatment and group B: received $10 \mathrm{mg} \backslash \mathrm{kg} \backslash$ day of acrylamide orally from day 7 (D7) of gestation until birth. While, group C received the same dose and route of acrylamide from D7 of gestation until postnatal day (PD) 21 . The male pups of each group were divided into subgroups according to the PD of sacrifice; PD7, PD14, and PD21 respectively. Cerebellum specimens were processed for light microscopy, immunohistochemistry, morphometeric and statistical studies.

Results: With acrylamide treatment, the general observation revealed signals of neurological abnormalities. There were histopathological degenerative changes in the architecture of the cerebellum of all treated groups. These changes were greatly increased from group B to group C. Postnatally, pia mater detachment, cavitations, hemorrhage within folds and degenerated changes of all granular layers and Purkinje cells (PC) were observed. Statistically, a highly significant decrease in the thickness of external granular layer and number of normal PC was revealed in groups $\mathrm{B}$ and $\mathrm{C}$ when compared with group A. While area \% of the bcl-2 immunoexpression showed a high significant increase.

Conclusion: Acrylamide adversely affected the structure of the developing cerebellum of albino rat offspring exposed during gestation and lactation periods. The severity of these changes was increased with longer period of exposure. Further measures should be needed to minimize acrylamide formation in food.
\end{abstract}

Received: 31 January 2019, Accepted: 13 April 2019

Key Words: Acrylamide, albino rat offspring, Bcl-2, developing cerebellum.

Corresponding Author: Hanan E.L. Mokhtar, MD, Anatomy and Embryology, Faculty of Medicine, Zagazig University, Egypt, Tel.: +20 1119532265, Email: lotfyann@gmail.com - lotfyann@yahoo.com

ISSN: 1110-0559, Vol. 42, No. 4

\section{INTRODUCTION}

In the last years, the major change in the life style and the feeding pattern as well as usage of some industrial chemicals lead to production of some substances that were not previously present such as; acrylamide (ACR $)^{[1]}$. ACR is a type- 2 alkene monomer and is a potent neurotoxin, causing disassembly or rearrangement of intermediate neurofilaments. Exposure of humans and animals to ACR produced a neurotoxic syndrome characterized by ataxia, skeletal muscle weakness and weight loss. So, it constitutes a severe human health problem ${ }^{[2]}$.

The major concerns associated with ACR were the sources of exposure; occupational exposure and drinking water. It is used in wastewater treatment processes, pulp and paper processing, mining and mineral processing and in the laboratory as a solid support for the separation of proteins by electrophoresis ${ }^{[1]}$.

In fast food restaurants, all over the world, potato chips become a common component of children's menu. These familiar foods contained high levels of toxic and carcinogenic products which are not found in the uncooked foods. Surprisingly, high levels of ACR were detected in widely consumed food items, notably; potato chips and even bread ${ }^{[3]}$.

In addition, the carbohydrate-rich food, cooked at high temperature contained high levels of ACR. Some evidence suggested that exposure to large doses of ACR injured the male reproductive glands. Direct exposure to pure acrylamide by inhalation, skin absorption, irritates the exposed mucous membranes (e.g., the sinuses) ${ }^{[4]}$.

On the other hand, a high level $(0.03-0.43 \mathrm{nmol} / \mathrm{g})$ of the acrylamide-adduct, was found in smokers due to presence of ACR in tobacco smoke. Smoking women with excess dietary exposure to ACR had significantly higher acrylamide-adduct levels in comparison to smoking women with low dietary exposure ${ }^{[5]}$.

Exposure to less than $1.0 \mathrm{mg} / \mathrm{kg} / \mathrm{day}$, ACR leads to developmental retardation and decreased body weight gain $^{[6]}$. Other studies have documented body weight reductions induced by acrylamide administered intrauterine. Acrylamide can cross the human placenta and has also been detected in breast milk ${ }^{[7]}$. 
LoPachin $^{[8]}$ mentioned that ACR is a neurotoxin with a great affinity for the peripheral ends of the spinal nerves in the extremities. ACR exposure in human has been associated with polyneuropathy with motor and sensory impairment marked by numbness, paresthesias, and ataxia, tremor, dysarthria and midbrain lesions. Ingestion of contaminated drinking water has caused drowsiness, disturbances of balance, confusion, memory loss and hallucinations.

Regardless the dose-rate, LoPachin et al. ${ }^{\left[{ }^{[0]}\right.}$ added that ACR intoxication was associated with early progressive degeneration of distal axons in the PNS and CNS and with cerebellar Purkinje cell injury.

The neurotoxicity of ACR on the spinal cord, cerebrum and brain stem was proved ${ }^{[10,11]}$. Although, the nervous components are considered the main target in ACR toxicity, few studies were done on the effect of ACR on the embryonic and postnatal development of cerebellum ${ }^{[12]}$

Therefore, the current study aimed to elucidate the possible structural changes that may occur in cerebellum of male albino rat offspring after oral administration of acrylamide to their pregnant and lactating mothers by using light microscopy, immunohistochemistry, morphometric and statistical studies.

\section{MATERIALS AND METHODS}

\section{Chemicals}

Acrylamide, a water-soluble chemical (purity $>99 \%$ - purchased from El-Gomhoria Chemical Company) was dissolved in distilled water and orally administered $(10 \mathrm{mg}>$ kg\day) by gastric intubation ${ }^{[13]}$. The present chronic dose was applied because the overdoses will reduce reproductive activity of mothers and cause paralysis ${ }^{[14]}$.

\section{Animals}

81 albino rats; 54 adult females and 27 adult males, weighing 200-250g, were utilized for mating. These rats were obtained from the Laboratory Animal Unit, Faculty of Medicine, Zagazig University. The animals were kept under good hygienic conditions. They were housed in fan ventilated wide polypropylene cages with stainless steel tops and wood shavings for bedding. Temperature was maintained at $23 \pm 2^{\circ} \mathrm{c}$. The animals were given a standard diet and water.

The experiment was performed according to the "Guide for the Care and Use of Laboratory Animals" (Institutes of laboratory Animal Research) ${ }^{[15]}$. It has been reviewed and approved by Institutional Animal Care and Use Committee Zagazig University. Approval number: ZU-IACUC/3/F/106/2018.

Experimental procedures: adult females were housed with adult males at ratio of 2:1 respectively in each cage. Then, vaginal smears were taken in next day to detect occurrence of pregnancy. The presence of sperm in the vaginal smears determined day one of gestation. The pregnant female rats were equally divided into three groups as follow:

Group A (control group): contained 18 pregnant rats which did not received any treatment.

Group B (prenatal treated group): contained 18 pregnant rats which were given $10 \mathrm{mg} \backslash \mathrm{kg} \backslash$ day of acrylamide by gastric intubation from the $\mathrm{D} 7$ of gestation until birth.

Group C: (perinatal treated group): contained 18 pregnant rats which were given $10 \mathrm{mg} \backslash \mathrm{kg} \backslash$ day of acrylamide by gastric intubation from D7 of gestation until D21 after birth.

At birth, each mother was housed with its pups in a large cage in a ventilated room at a constant temperature $\left(25^{\circ} \mathrm{c}\right.$. $)$ with a12:12 h light/ dark cycle. Each group contained first generation of male pups with their mothers. Then, the pups were divided into three subgroups (10 male pups for each) according to the postnatal day of sacrifice as follow:

Subgroups AI, BI and CI: sacrificed after 7 days postnatally (PD7).

Subgroups AII, BII and CII: sacrificed after 14 days postnatally (PD14).

Subgroups AIII, BIII and CIII: sacrificed after 21 days postnatally (PD21).

After animal sacrifice by decapitation, the heads were dissected for obtaining the cerebellar biopsies. The specimens were immediately processed for light microscopic examination.

\section{1- Preparation for Light Microscopy}

The cerebellar specimens were fixed in $10 \%$ paraformaldehyde in phosphate buffer $(\mathrm{PH}=7.4)$ for 48 hours. In ascending grades of alcohol $(50 \%, 70 \%, 90 \%$ and $95 \%$ ), the samples were dehydrated each for one hour. Then, in absolute alcohol (100\%), two changes one hour for each. After clearing in xylene, samples were embedded in soft paraffin wax at $55{ }^{\circ} \mathrm{C}$ for 2 hours and in hard paraffin at $60{ }^{\circ} \mathrm{C}$ for another 2 hours. Sections of $5 \mu \mathrm{m}$ thick were prepared to be stained with Hematoxylin and Eosin $(\mathrm{H} \text { and } \mathrm{E})^{[16]}$. The cerebellar sections were examined and photographed in Histology Department, Faculty of Medicine, Zagazig University.

\section{2- Immunohistochemical procedure ${ }^{[17,18]}$}

This was performed using the avidin biotin peroxidase system for localization apoptotic cells. The mouse monoclonal anti-Bcl-2 antibody (an anti-apoptotic marker, bcl-2; SC-7382) was delivered from Sigma Laboratories (Code No. 00114386). In brief, paraffin sections of $4 \mu \mathrm{m}$ thickness were deparafinized in xylene for 60 minutes and progressively dehydrated in graded ethanol $(100 \%, 95 \%$, $80 \%, 70 \%$; each for 5 minutes). To block endogenous peroxidase activity, the sections were immersed in $3 \%$ $\mathrm{H}_{2} \mathrm{O}_{2}$ in distilled water for 10 minutes. The sections were covered with primary antibody (approximately $100 \mu \mathrm{l}$ per 
a section) and were incubated in a humid chamber at room temperature overnight. Then, each section was covered with biotinylated secondary anti-mouse antibody, diluted 1:500. Phosphate buffered saline PBS $(\mathrm{pH}=7.4)$ was used for all subsequent washes. Visualization of the bound primary antibodies was performed with diaminobenzidine (DAB) solution as a chromogen and counterstained with Mayer's Hematoxylin. Bcl-2 immunoreactions were expressed as fine brown reaction product in cytoplasm of the cells, whereas the background stained blue.

\section{3- Image analysis and morphometric study}

Stained sections with $\mathrm{H}$ and $\mathrm{E}$ and with anti-Bcl-2 antibody (magnification $\times 400$ ) were morphometrically analyzed using software Leica Qwin 500 (Leica imaging system, Ltd, Cambridge, England) in the image analysis unit in Histology and Cell Biology Department, Faculty of Medicine, Cairo University. The image analyzer was first calibrated automatically to convert the measurement units (pixels) produced by the image analyzer program into actual micrometer units. Various fields were chosen and 5 readings were obtained from each slide. This image analyzer computer system was used to measure the following parameters:

1. The thickness of external granular layer of cerebellum ( $\mathrm{H}$ and $\mathrm{E}$ stained sections $\times 400)$ by using the interactive measure menu (Figure A).

2. Number of normal Purkinje cells ( $\mathrm{H}$ and $\mathrm{E}$ stained sections $\times 400$ ) by using the interactive measure menu (Figure B).

3. Theareapercentage(\%)of Bcl-2immunoexpression in Purkinje cells (immunohistochemical stained sections $\times 400$ ). The measuring field menu for standard measuring frame of an area equal to $118476.6 \mu \mathrm{m} 2$. The immunoexpression for Bcl2 area was masked by a green binary color to be measured (Figure C).

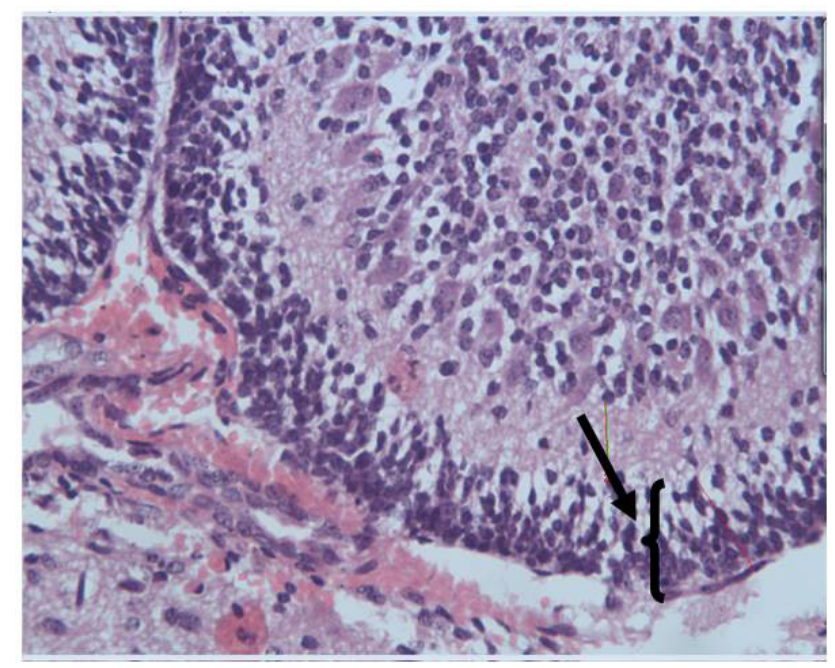

Fig. A: A photomicrograph of a section of rat cerebellum showing the method of measuring the thickness of the external granular layer in the field. $(H \& E \times 400)$.

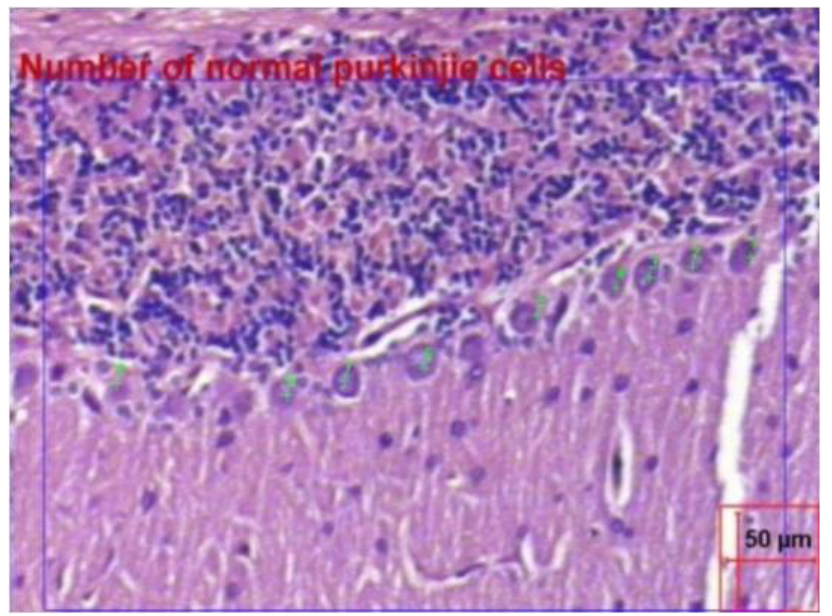

Fig. B: A photomicrograph of a section of rat cerebellum showing the method of counting of the number of normal Purkinje cells in the field. $(\mathrm{H} \& \mathrm{E} \times 400)$.

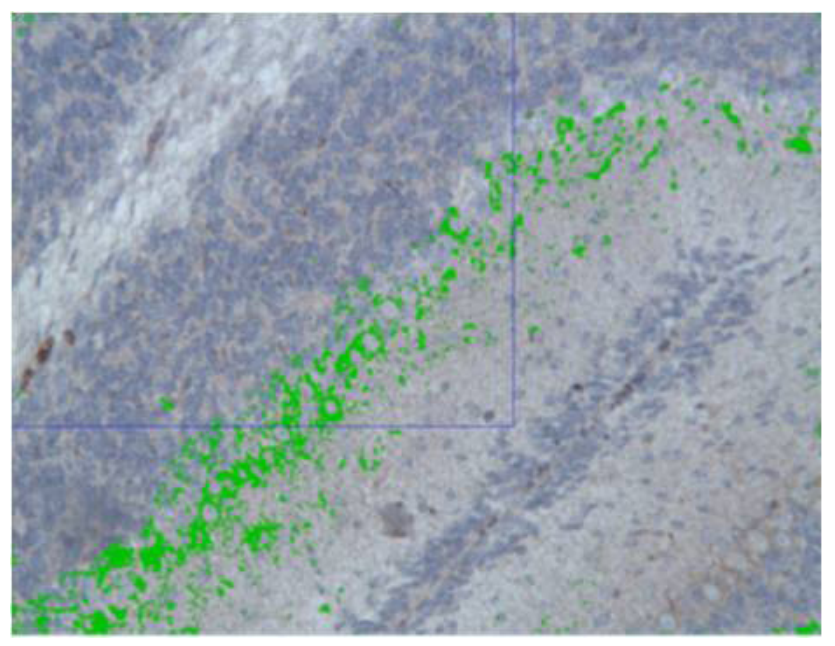

Fig. C: A photomicrograph of a section of rat cerebellum showing the method of measuring the area \% of positive bcl2 immunoreactions masked by green binary. $(\mathrm{Bcl}-2 \mathrm{IHC} \times 400)$.

\section{Statistical analysis}

The obtained data (the thickness of EGL, normal Purkinje cell number, and area $\%$ of $\mathrm{Bcl}-2$ positive immunoexpression) were analyzed statistically using SPSS version 11. The one-way analysis of variance (ANOVA) was done for comparison between the different groups (more than two groups) with $p$ value $\leq 0.05$ (the level of significance). Post hoc test was used to find the statistical difference between the groups when ANOVA was statistically significant $(P \text { value } \leq 0.05)^{[19]}$.

\section{RESULTS}

\section{General observations}

Some pregnant rats treated with ACR had suffered from abortions close to day of delivery. An abnormal behavior of some mothers towards their pups were noted. Many of them eat their all pups immediately after their delivery. This behavior thought to be attributed to neurotoxicity of ACR. 
Also, the pups of groups $\mathrm{B}$ and $\mathrm{C}$ showed signals of different neurological abnormalities: progressive muscle weakness, abnormal posture of the foot or leg, development of gait abnormalities and unsteady pattern of walking which started at the hind limbs and progressed to the forelimbs leading to dragging of the limbs during walking especially in group C.

\section{A-Light microscopic examination}

\section{1-Cerebellar sections of PD7 albino rats (subgroups AI, BI and CI)}

In control albino rat, the normal architecture of the cerebellum was divided into several well defined short broad folds separated by less deep narrow sulci. Each fold was consisted of a cerebellar cortex and less defined and less differentiated white matter core which was continuous with the central white matter (Figure 1a). The cerebellar cortex was formed of four layers which were arranged from superficial to deep as follow; outer thick external granular layer (EGL) (covering the fold surfaces and lining the sulci), molecular layer (ML), Purkinje cell layer (PCL) and internal granular layer (IGL) (Figure 1b). The outermost EGL layer was thick and packed with 5-6 rows of rounded darkly stained granule cells. Relatively thin ML was resident between EGL and PCL and composed of few small neuronal cell bodies, nerve fibers and dendrites of Purkinje cell. The PCL arranged in single row and showed large pear shaped cells with large vesicular nuclei containing prominent nucleoli. The Purkinje cells sent different processes called dendrites extending into ML while, the axons extending into the IGL. The IGL was formed of moderately populated granule cells which appeared as small rounded scattered deeply stained cells (Figure 1c)

Prenatal exposure to ACR produced degenerative changes at PD7 albino rats. The cerebellar folds appeared long and separated by narrow less deep or wide deep sulci. The cerebellar folds also showed two degenerative damages i.e.; detachment of pia matter covering their surface and presence of some cavitations within their matrix. Less thick EGL covering surfaces of the folds or lining the sulci was seen when compared with control of same age group (Figure 2a). External granular layer appeared packed with pyknotic deeply stained granule cells with ill-defined feature. The molecular layer showed vacuolated matrix and vacuolated cells giving it a spongiform appearance. The Purkinje cells appeared hazy and showed different degree of distortion in the form of disrupted irregular cell membrane, disintegrated cell membrane with karyolysis or loss of cell membrane with ill-defined nucleus. However, some areas revealed complete absence of Purkinje cells. The internal granular layer contained large vacuolation and ill-defined degenerated granule cells aggregated into groups (Figure 2b).

The perinatal exposure to ACR at PD7, albino rats showed more complicated picture in the cerebellar structure. Constricted cerebellar folds separated by short wide sulci were seen. The external granular layer appeared less thick and was exfoliated at certain places. Some extravasated hemorrhagic blood accumulated between the cerebellar folds was demonstrated (Figure 3a). The higher magnification illustrated more clearly severe effect of the acrylamide. The external granular layer appeared packed with deeply stained pyknotic granule cells with illdefined feature. The molecular layer appeared destructed and slightly vacuolated with loss of dendritic arborizations of PC. The Purkinje cells showed distorted arrangement and different degrees of degeneration (shrinkage and complete degeneration, deep staining with disruption of cell membrane and ill-defined nucleus). Internal granular layer appeared highly vacuolated and consisted of sparsely populated deeply stained degenerated granule cells (Figure 3b).

\section{2- Cerebellar sections of PD14 albino rats (subgroups AII, BII and CII)}

At PD14, the cerebellum of control albino rat showed many long folds separated by deep compressed sulci. Less thick EGL lining the sulci or covering surfaces of the cerebellar folds was demonstrated. The cerebellar folds contained narrow well defined core of white matter and easily distinguished from IGL (Figure 4a). Less thick EGL was consisted of 3 or 4 rows of granule cells. The molecular layer started to increase in width. The Purkinje cell layer was still arranged in single row between ML and IGL. The internal granular layer was more differentiated from white matter core and exhibited highly populated granule cells (Figure 4b). With a higher magnification, the Purkinje cells appeared as a large spherical neuron with large less stained nuclei and prominent nucleoli. Network of dendrites of Purkinje cells (forming arborizations) accumulated in the molecular layer making it wide. However, the IGL was packed with more condensed granule cells characterized by their dark blue density appearance (Figure 4c).

Prenatal treated cerebellum of PD14 albino rat showed long and short broad cerebellar folds separated by compressed deep and less deep sulci. Very thin EGL was demonstrated covering the folds and lining the sulci. Wide core of white matter was seen deeply penetrated the fold. In certain areas, IGL increased in width and thickness and showed obvious herniation (Figure 5a). Most of Purkinje cell appeared degenerated and deeply stained with karyorrhexis or karyolysis. They were surrounded by wide peri-cellular spaces with loss of their axons. The internal granular layer showed vacuolation of different sizes between their cells. The granule cells appeared greatly damaged, clumped in groups and enclosed by edematous spaces (Figure $5 b$ ).

The perinatal treated cerebellum of PD14 albino rat showed marked degenerative changes. Convoluted cerebellar folds with certain detachment through their layers were observed. Very thin layer of EGL covering the surface or lining the sulci was demonstrated. In some areas, 
IGL increased in width and thickness and showed obvious herniation (Figure 6a). At a higher magnification, obvious sloughing and complete separation between IGL and PCL was demonstrated. Most of Purkinje cells appeared deeply stained with pyknotic ill-defined nucleus and lost their axons. The internal granular layer appeared packed with deeply stained, degenerated granule cells with ill-defined feature and aggregated in groups and were surrounded by edematous spaces (Figure 6b).

\section{3- Cerebellar sections of PD21 albino rats (subgroups AIII, BIII and CIII)}

At PD21 of control albino rat, long and well defined folds separated by more deep and wide sulci were observed. The external granular layer that covering surfaces of the cerebellar folds or lining the sulci was absent. The molecular layer appeared more increased in width and in density than previous age. The internal granular layer appeared thick and sharply differentiated from the narrow white matter core (Figure 7a). The molecular layer contained fewer number of vertically oriented spindle shaped migratory cells and intensive well-formed dendritic arborizations of Purkinje cells. The Purkinje cells were still arranged in single row to form PCL. They appeared as spherical and pear shaped cells with large intensely stained nuclei and prominent nucleoli. However, IGL appeared packed with granule cells which were characterized by their dark blue density and rounded appearance (Figure 7b).

At PD21 of prenatal treated albino rat, showed short and long cerebellar folds separated by deep, more wide and crude sulci. The external granular layer appeared absent except at certain places, it was still present as single row of cells covering some cerebellar folds. The molecular layer appeared wide in certain sites and narrow in others. Internal granular layer appeared thick with some degree of herniation at certain places. Wide core of white matter was deeply penetrated the fold and sharply demarcated from IGL (Figure 8a). The Molecular layer appeared hazy and edematous with loss of dendritic arborizations of PC and contained some vacuolated cells. Different sever degrees of distortion of Purkinje cells were seen (in the form of disrupted cell membrane, with ill-defined nucleus or with karyolysis, loss of their axons, and enclosing by wide pericellular spaces). The internal granular layer exhibited large vacuoles, degenerated granule cells clumped in clusters with edematous spaces in between (Figure 8b).

At PD21 of perinatal treated albino rat, showed marked degenerative changes. Distorted cerebellar folds with several cracks disfiguring its normal architecture and detaching their layers were seen. The external granular layer was still present as single row of cells lining the wide deep sinus. The molecular layer appeared of variable thickness in different areas (Figure 9a). Also there was a sever detachment and separation between PCL and IGL. Narrow core of white matter appeared destructed and discontinuous. In addition, IGL displayed deeply penetrating cracks with some areas of hemorrhage (Figure 9b).

At higher magnification, obvious sloughing and complete separation between PCL and IGL was demonstrated and most of Purkinje cells were distorted losing their dendrites and axons. Few Purkinje cells appeared deeply stained degenerated, losing their axons and still attached to IGL. The molecular layer appeared hazy and edematous with loss of dendritic arborizations of PC. The internal granular layer was packed with deeply stained degenerated granule cells aggregated in groups and surrounded by edematous spaces (Figure 9c).

\section{2- Immunohistochemistry}

The expression of bcl-2 was negative to mild in control group, was moderate in prenatal treated group while was intense in perinatal treated group [Figure 10 (a-i)].

\section{3- Statistical results}

1. The thickness of EGL showed highly significant decreased from group A to group $\mathrm{C}(P<0.001)$ at PD7 but was significantly decreased at PD14 $(P<0.006)$ (Table 1 and Figure 11).

2. The number of normal Purkinje cells showed a highly significant decrease in the number of normal cells from group A to $\mathrm{C}(P<0.001)$ through different studied postnatal days (Table 2 and Figure 12).

3. The area \% of bcl-2 immunoexpression in Purkinje cells showed a highly significant increased in both group $\mathrm{B}$ and $\mathrm{C}$ compared to the control group $\mathrm{A}$ $(P<0.001)$ through different studied postnatal days (Table 3 and Figure 13). 


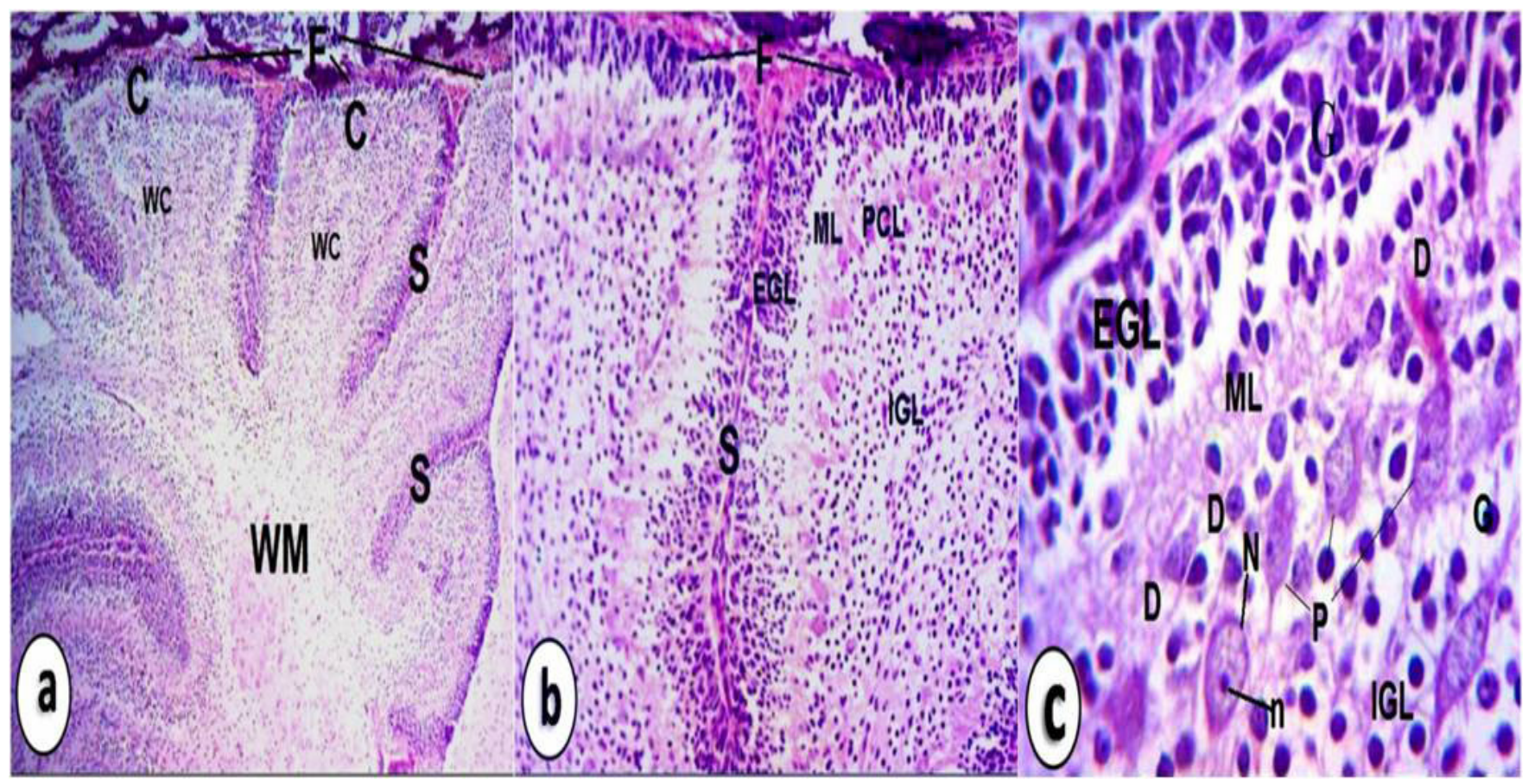

Fig. (1.a-c): Photomicrographs of control cerebellar sections of PD7 male albino rat. [a]: showing short broad folds (F) separated by less deep narrow sulci (S). Each fold is covered by a cerebellar cortex $(\mathrm{C})$ with less defined core of white matter $(\mathrm{WC})$ continuous with the central white matter $(\mathrm{WM})$. $(\mathrm{H} \& \mathrm{E} \times 100)$. [b] showing the four layers cerebellar cortex; external granular layer (EGL), molecular layer (ML), Purkinje cell layer (PCL) and internal granular layer (IGL). Notice thick EGL lining the sulci (S) and covering the cerebellar folds (F). (H\&E $\times 200)$. [c]: showing EGL packed by rounded darkly stained granule cells. The Purkinje cells (P) are large pear shaped with vesicular nuclei (N) and prominent nucleoli (n). Dendritic cell processes (D) are seen extending into ML. The internal granular layer (IGL) contained scattered deeply basophilic stained granule cells (G). (H\&E ×400).

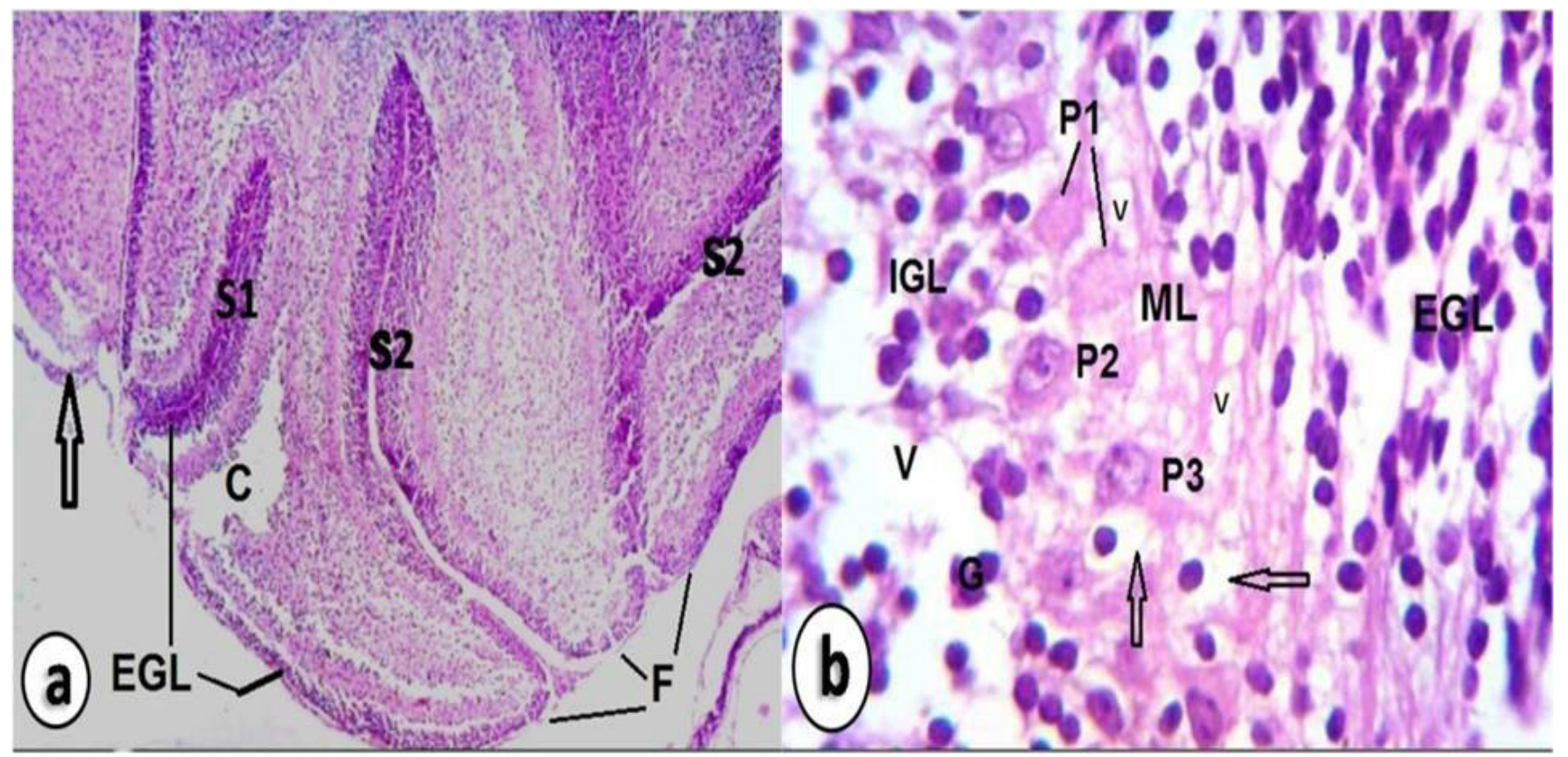

Fig. (2.a-b): Photomicrographs of cerebellar sections of prenatal treated group of PD7 male albino rat. [a]: showing long cerebellar folds (F) separated by narrow less deep (S1) or wide deep sulci (S2). Small cavity (C) is apparent within their matrix. Less thick external granular layer (EGL) is seen covering surfaces of folds (F) or lining the sulci. Notice the pial detachment covering some folds (arrow). (H\&E $\times 100)$. [b]: showing EGL packed with pyknotic deeply stained granule cells. The molecular layer shows vacuolated matrix (V) and vacuolated cells (arrow). Purkinje cells (P1) shows disintegrated cell membrane with karyolysis, (P2) with disrupted cell membrane and (P3) with loss of cell membrane and ill-defined nucleus. The internal granular layer (IGL) shows large vacuolation $(\mathrm{V})$ and degenerated granule cells aggregated into groups $(\mathrm{G})$. (H\&E $\times 400)$. 


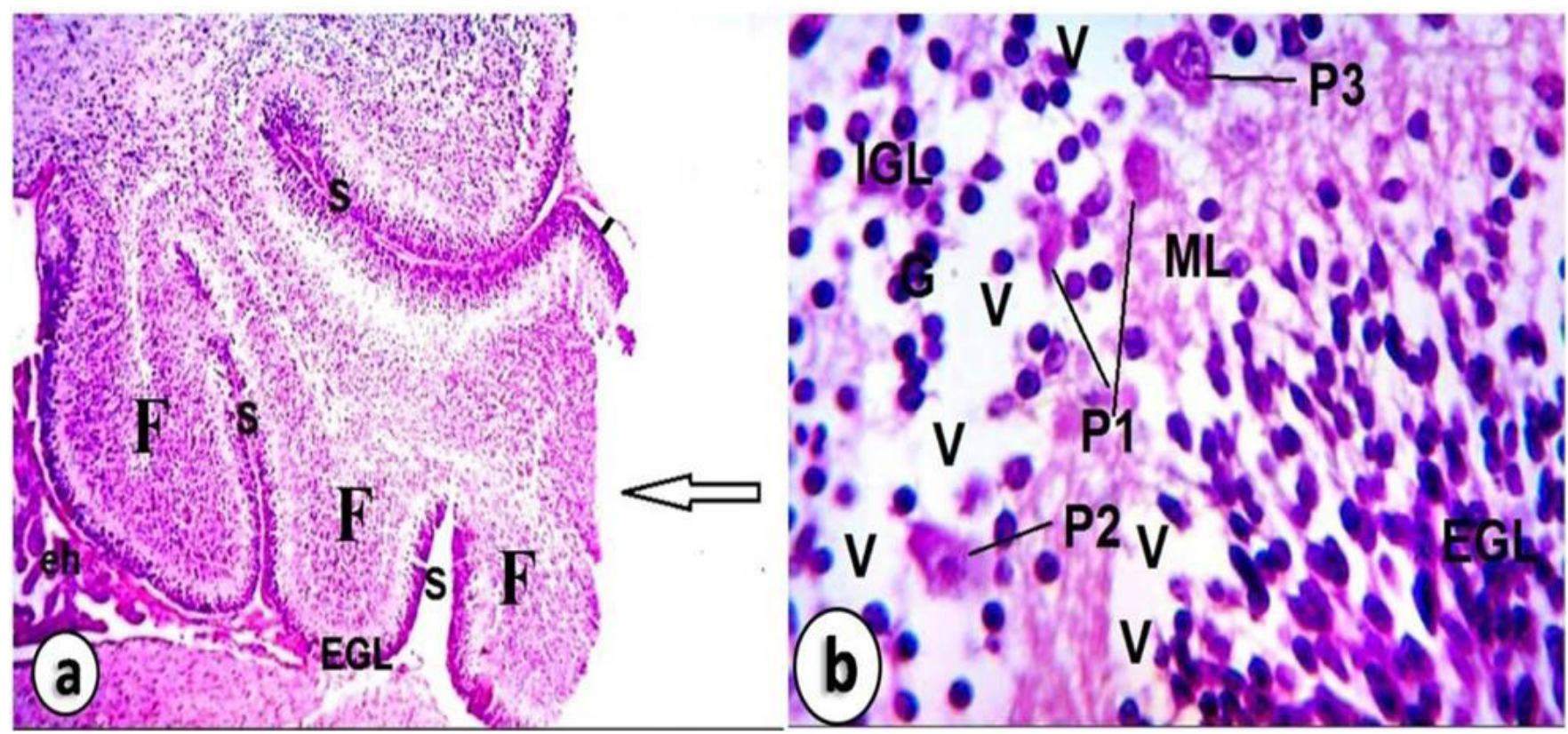

Fig. (3.a-b): Photomicrographs of cerebellar sections of perinatal treated group of PD7 male albino rat. [a]: showing some constricted cerebellar folds (F) separated by short wide sulci (S). The external granular layer appears less thick and exfoliated in certain places (arrow). Notice some extravasated hemorrhagic blood (eh) accumulated between the folds. (H\&E $\times 100)$. [b]: showing EGL packed with deeply stained granule cell. The molecular layer appears destructed and slightly vacuolated (V). Purkinje cells show distorted arrangement; (P1) with shrinked and completely degenerated, (P2) with disrupted cell membrane and ill-defined nucleus and (P3) appeared deeply stained with irregular cell membrane. The internal granular layer (IGL) shows large vacuolations (V) and sparsely populated deeply stained granule cells $(\mathrm{G})$. $(\mathrm{H} \& \mathrm{E} \times 400)$.

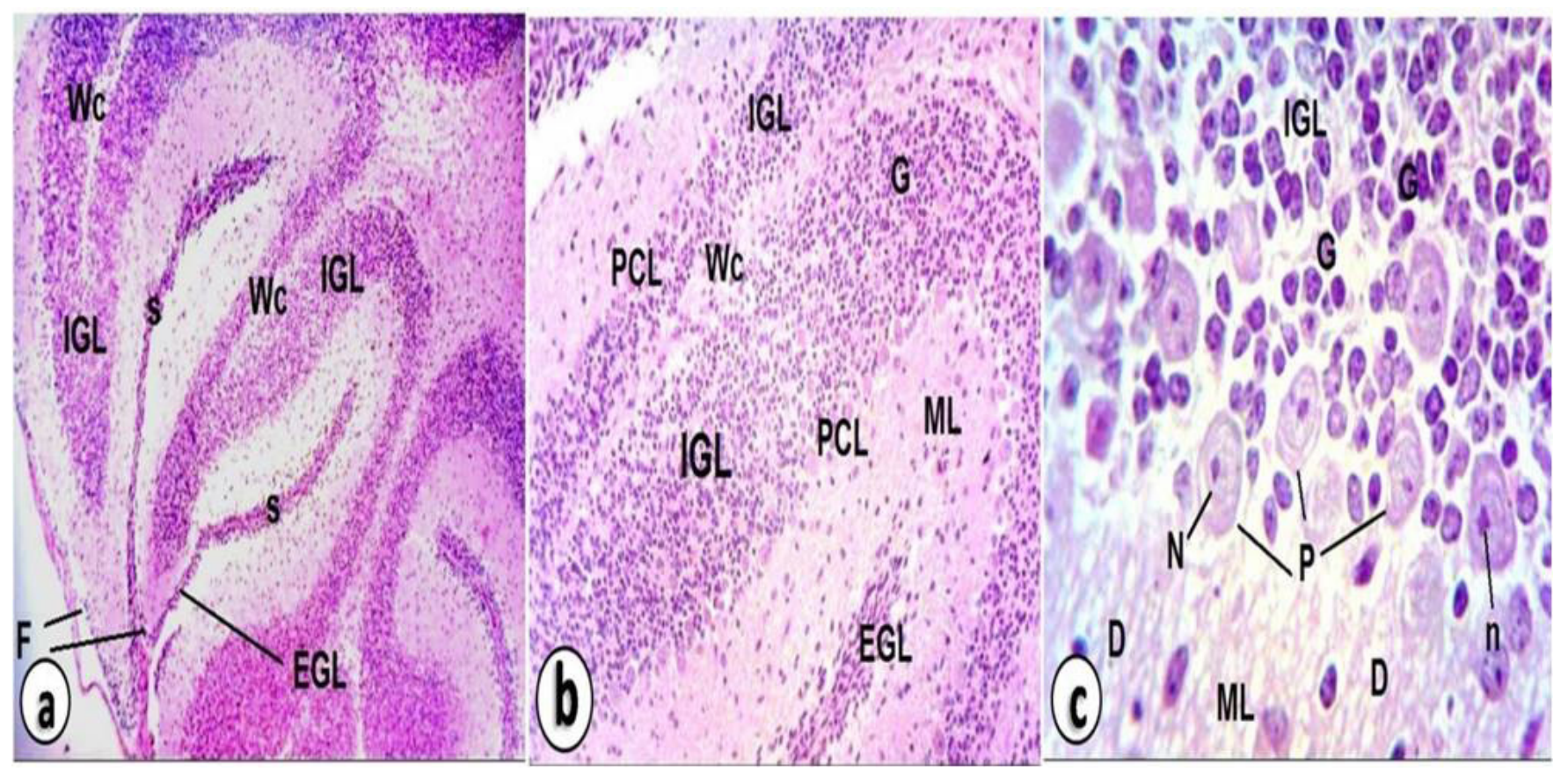

Fig. (4.a-c): Photomicrographs of control cerebellar sections of PD14 male albino rat. [a]: showing long cerebellar folds (F) separated by deep compressed sulci (S). White matter core (Wc) appear narrow and well defined from IGL. Notice less thick EGL covering the folds (F) and lining sulci (S) is seen. (H\&E $\times 100)$. [b]: showing EGL formed of 3 or 4 rows of granule cells. The molecular layer is increased in width. PCL is arranged in a single row between ML and IGL. The nternal granular layer is more differentiated from white matter core $(\mathrm{Wc})$ and exhibits highly populated granule cells $(\mathrm{G})$. $(\mathrm{H} \& \mathrm{E} \times 200)$. [c]: showing network of dendrites (D) of Purkinje cells accumulated in ML. The Purkinje cells (P) appear as large spherical with large less stained nuclei (N) and prominent nucleoli (n). The internal granular layer (IGL) appears packed with more condensed dark blue stained granule cells $(\mathrm{G})$. (H\&E×400). 


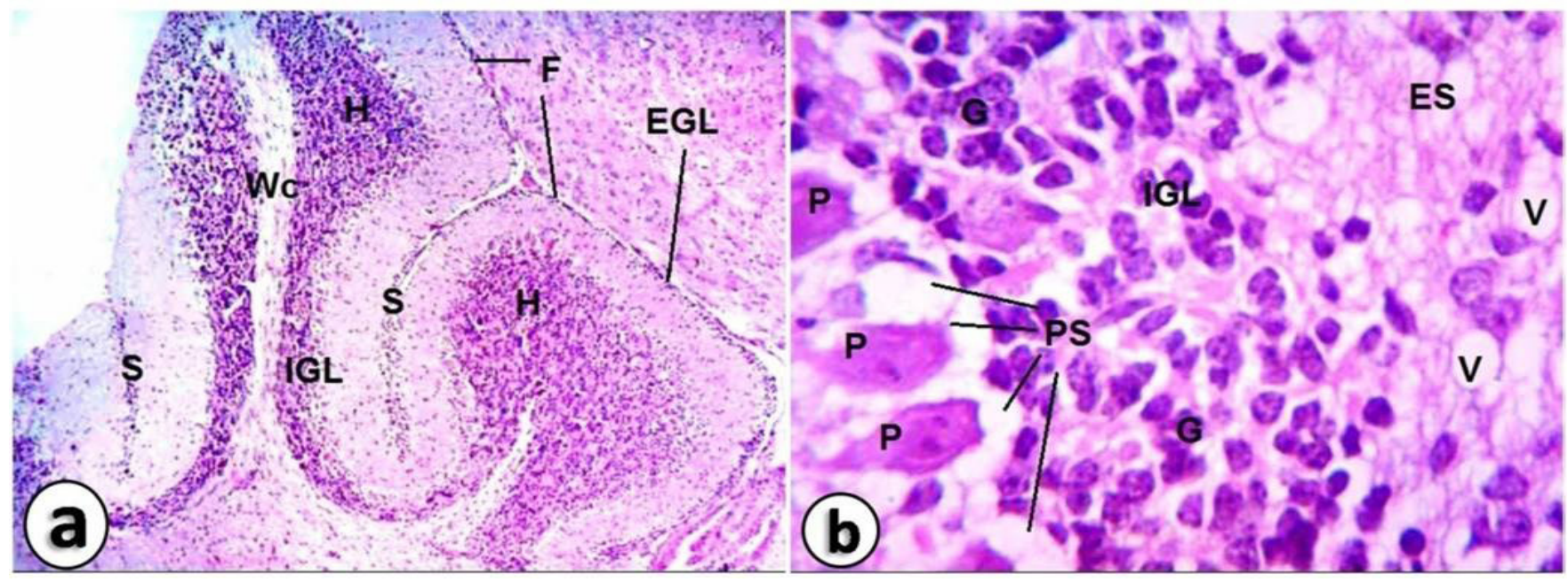

Fig. (5.a-b): Photomicrographs of cerebellar sections of perinatal treated group of PD14 male albino rat. [a]: showing long and short broad cerebellar folds (F) separated by compressed deep and less deep Sulci (S). Very thin EGL covering the folds (F) and lining the sulci (S) is seen. Wide core of white matter (Wc) is deeply penetrated the fold. Notice obvious herniation $(\mathrm{H})$ of IGL is demonstrated in certain sites. (H\&E $\times 100$ ). [b]: showing hazy and deeply stained Purkinje cells (P) surrounded by wide peri-cellular spaces (PS) with loss of their axons. The internal granular layer shows vacuolations (V) and edematous spaces (ES) between the granule cells which appear clumped in groups $(\mathrm{G}) .(\mathrm{H} \& \mathrm{E} \times 400)$.

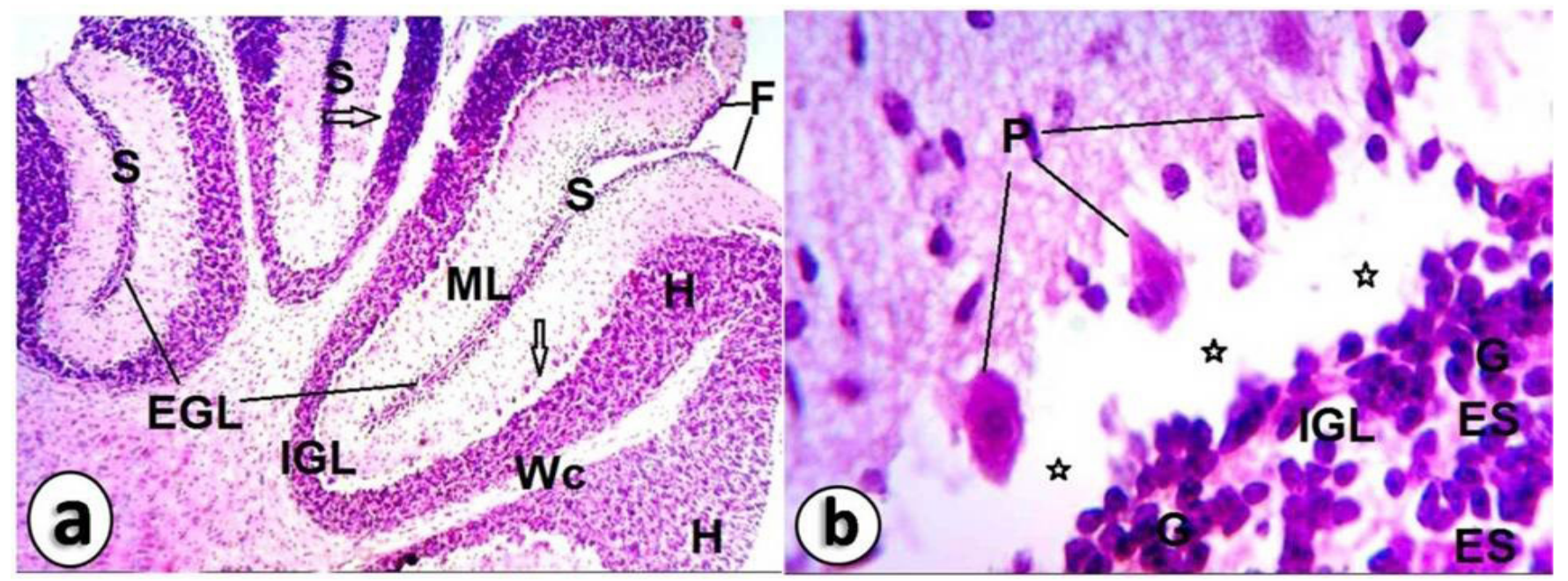

Fig. (6.a-b): Photomicrographs of cerebellar sections of perinatal treated group of PD14 male albino rat. [a]: showing some convoluted cerebellar folds (F) with detachment (arrow) of their layers. Very thin EGL covering the folds and lining the sulci (S) is seen. Thick IGL with obvious herniation (H) is well seen in certain areas. Notice narrow core of white matter $(\mathrm{Wc})$ deeply penetrated the fold. $(\mathrm{H} \& \mathrm{E} \times 100)$. [b]: showing obvious sloughing and complete separation $\left(^{*}\right)$ between IGL and PCL. The Purkinje cells (P) appear deeply stained with pyknotic nucleus. The internal granular layer shows deeply stained degenerated granule cells aggregated in groups $(\mathrm{G})$ surrounded by edematous spaces $(\mathrm{ES})$. (H\&E $\times 400)$. 


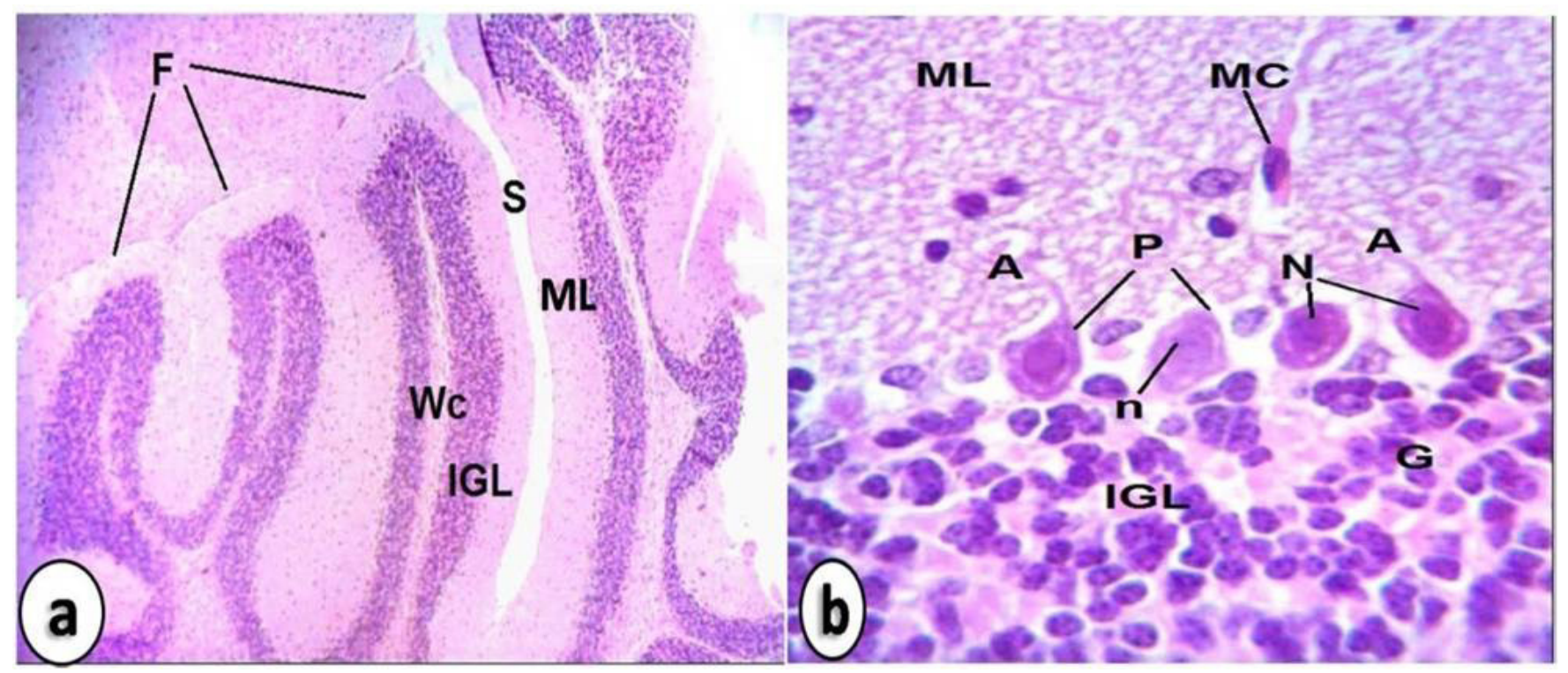

Fig. (7.a-b): Photomicrographs of control cerebellar sections of PD21 male albino rat. [a]: showing more long folds (F) and more deep wide sulci (S). Narrow white matter core $(\mathrm{Wc})$ is sharply demarcated from IGL. Notice absence of EGL. The molecular layer is more increased in width and in density. (H\&E $\times 100$ ). [b]: showing ML containing fewer number of spindle shaped migratory cells (MC) and dendritic arborizations (A) of Purkinje cells. The Purkinje cells (P) appear spherical or pear shaped cells with large intensely stained nuclei (N) and prominent nucleoli (n). The internal granular layer (IGL) appears packed with dark blue dense granule cells $(\mathrm{G})$. $(\mathrm{H} \& \mathrm{E} \times 400)$.

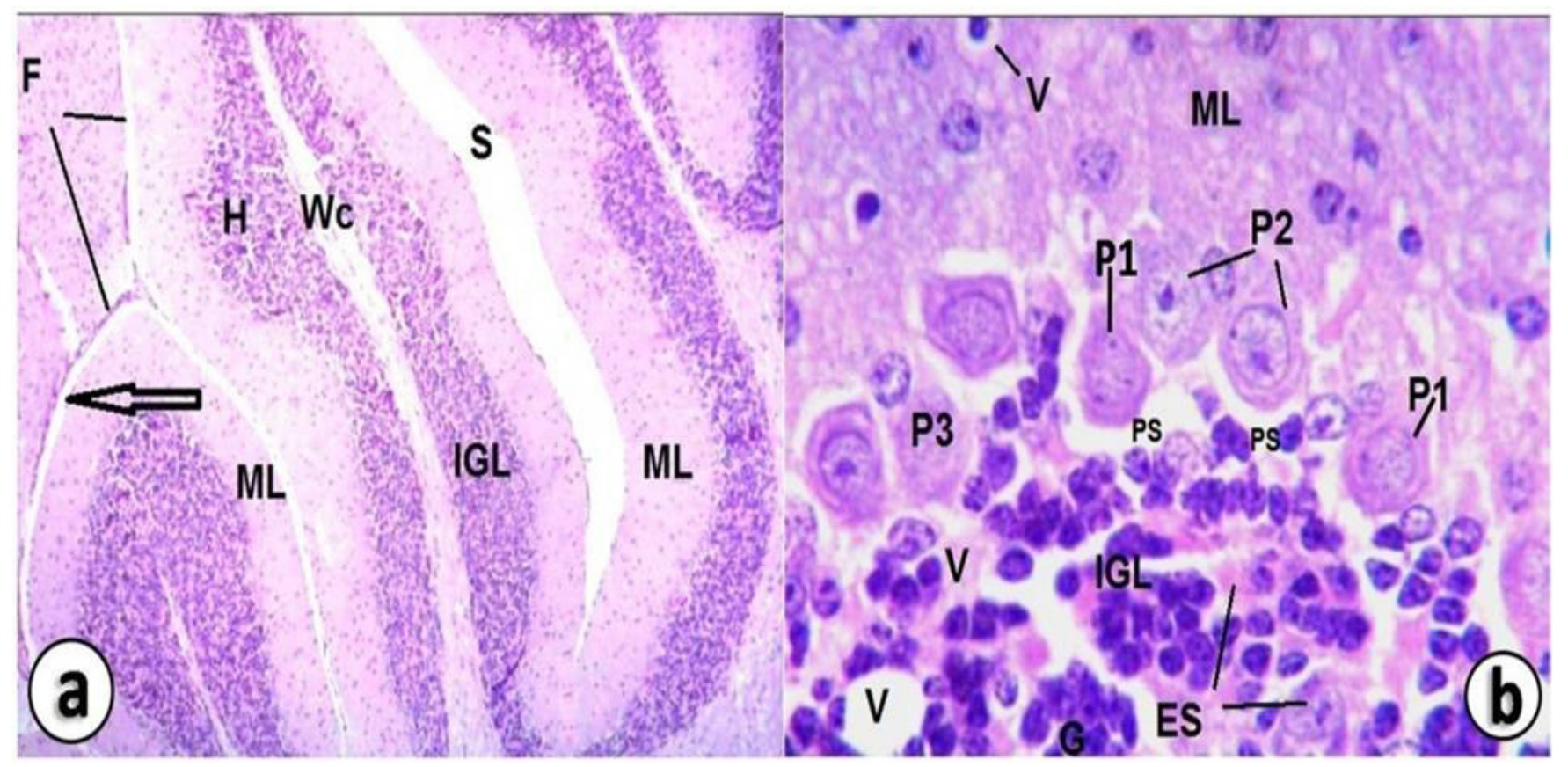

Fig. (8.a-b): Photomicrographs of cerebellar sections of prenatal treated group of PD21 male albino rat. [a]: showing short and long cerebellar folds (F) separated by deep wide and crude sulci (S). Notice EGL is still present covering surface as single row of cells (arrow). The molecular layer appears wide in certain sites and narrow in others. The internal granular layer is thick with obvious herniation $(\mathrm{H})$ at certain sites and sharply demarcated from wide core of white matter $(\mathrm{Wc})$. $(\mathrm{H} \& \mathrm{E} \times 100)$. [b]: showing hazy and edematous ML containing vacuolated cells (V) with loss of dendritic arborizations of PC. Purkinje cells (P1) shows disrupted cell membrane and ill-defined nucleus, (P2) with disrupted cell membrane and (p3) with karyolysis with loss of their axons. Notice wide peri-cellular spaces (ps) surrounding PC. The internal granular layer (IGL) exhibits large vacuoles (V), aggregations of degenerated granule cells (G) and edematous spaces (ES) in between. (H\&E $\times 400)$. 

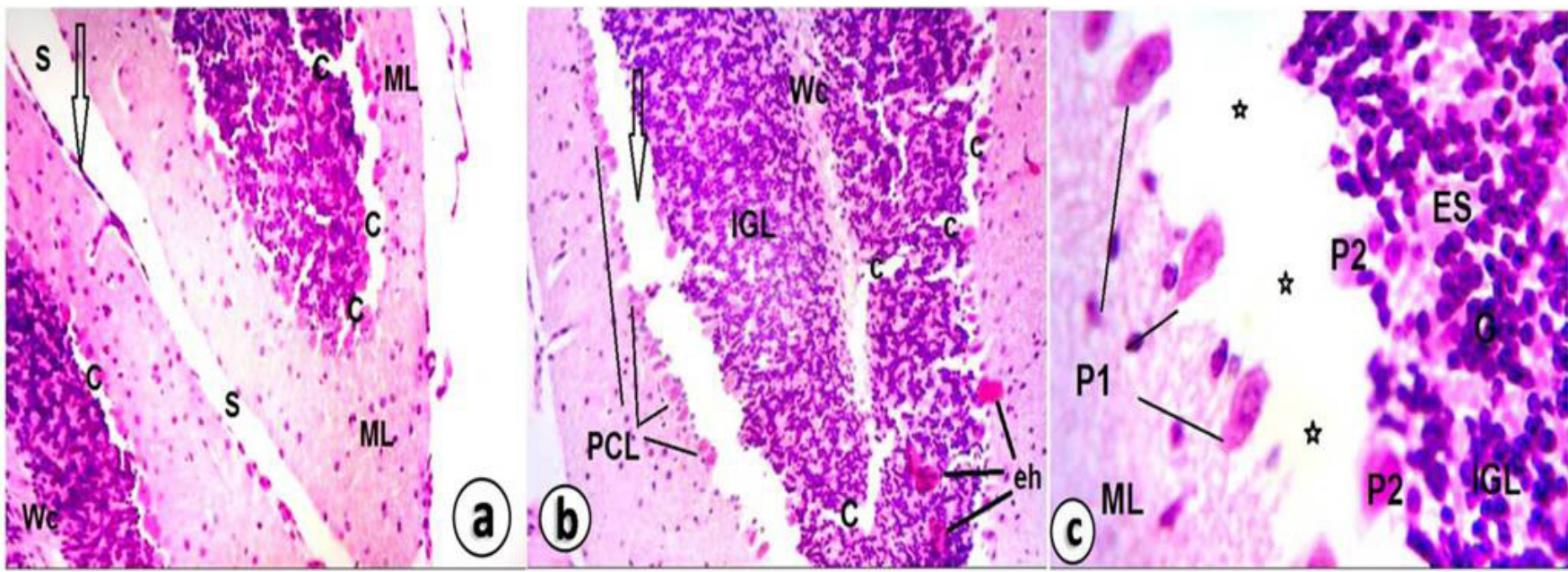

Fig. (9.a-c): Photomicrographs of cerebellar sections of perinatal treated group of PD21 male albino rat. [a]: showing several cracks (C) detaching the layers of the distorted folds. Single raw of EGL is still present lining the sinus (arrow). Notice thickness of ML. $(H \& E \times 100)[b]$ : showings sever detachment and separation (Arrow) of PCL from IGL. Discontinuous core of white matter (Wc) is seen. Cracks (C) appear deeply penetrating IGL with some areas of extravasated hemorrhage (eh). $(H \& E \times 200)$. [c]: Purkinje cells (P1) show deeply stained with ill-defined feature with losing of their axons, but (P2) appear completely degenerated and still attached to IGL. The molecular layer appears hazy and edematous. The internal granular layer (IGL) shows aggregation of degenerated granule cells $(\mathrm{G})$ surrounded by edematous spaces (ES). Notice obvious separation $(*)$ between IGL and PCL is seen. $(\mathrm{H} \& \mathrm{E} \times 400)$.
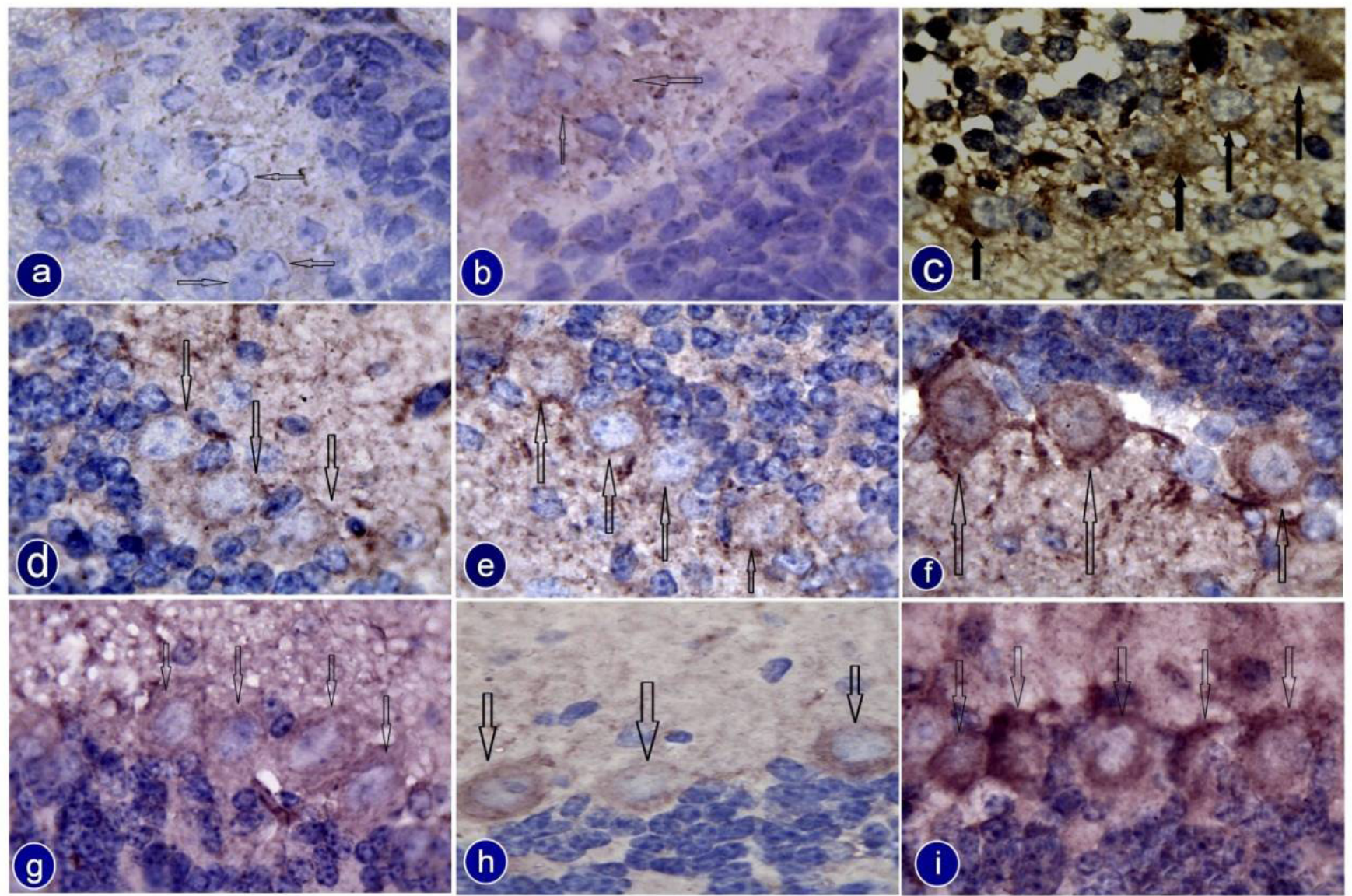

Fig. (10.a-i): Photomicrographs of cerebellar sections of male albino rats showing immunoreactive staining for bcl-2 in Purkinje cells (arrows). [a, d, g]: The control cerebellar sections showing negative [a] to mild $[\mathrm{d}, \mathrm{g}]$ expression of bcl-2. [b, e, h]: The prenatal treated cerebellar sections showing moderate expression of bcl-2 however, [c, f, i]: The perinatal treated cerebellar sections showing intense expression of bcl-2 in the degenerated Purkinje cells. (Anti-Bcl-2 $\mathrm{IHC} \times 1000)$ 


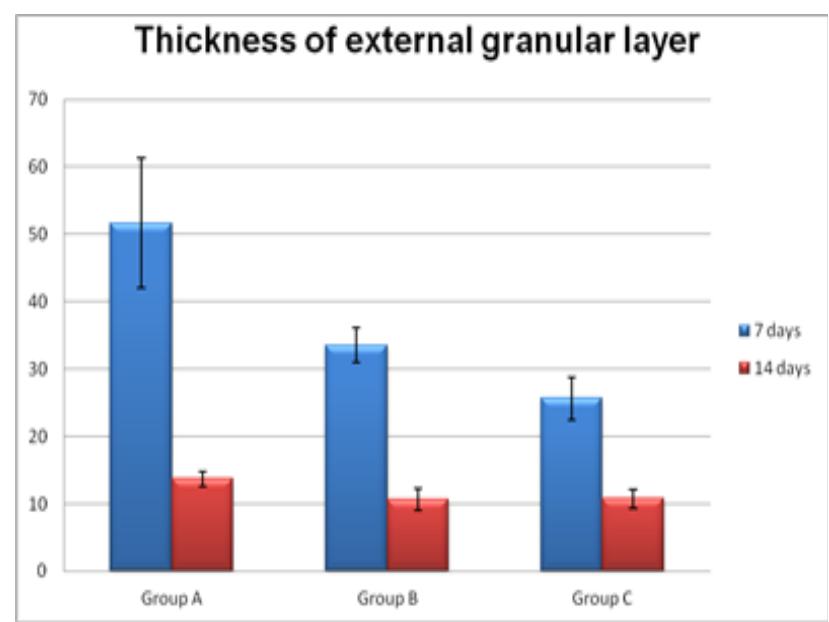

Fig. 11: Bar Chart showing statistical analysis of thickness of external granular layer of different groups at PD7 and PD14.

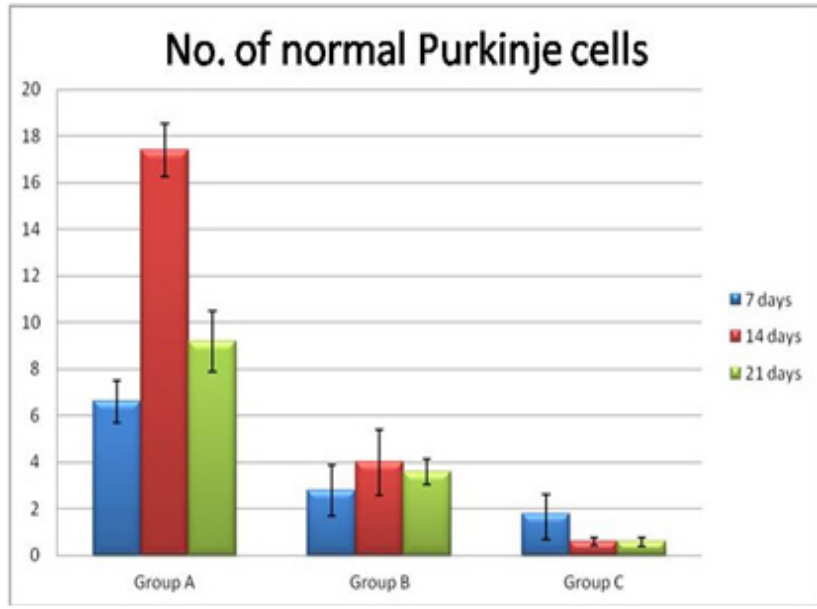

Fig. 12: Bar chart showing statistical analysis of No. of normal Purkinje cells in the different studied groups at PD7, PD14 and PD21.

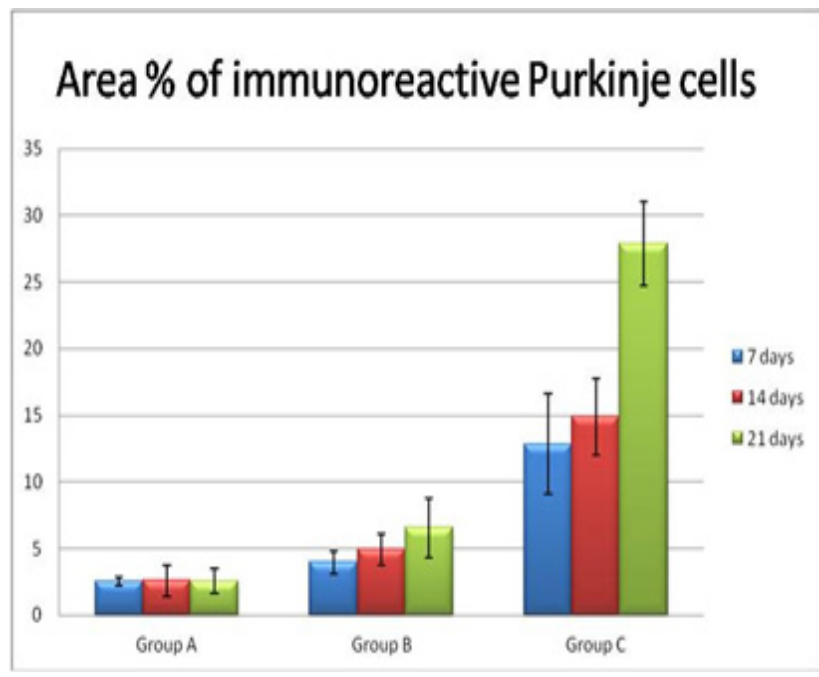

Fig. 13: Bar Chart showing statistical analysis of area $\%$ of positive immunoreactive Purkinje cells at PD7, PD14 and PD21.

Table 1: Statistical analysis of thickness of EGL in the different studied groups using one way ANOVA test.

\begin{tabular}{ccccccc}
\hline Postnatal day & Thickness of EGL: & Group A & Group B & Group C & F & P \\
\hline PD 7 & Mean \pm SD & $51.61 \pm 9.66$ & $33.53 \pm 2.63$ & $25.61 \pm 3.11$ & \multirow{2}{*}{24.25} & $<0.001^{* *}$ \\
& Range & $38.23-62.15$ & $30.15-37.22$ & $20.43-28.35$ & & \\
PD 14 & Mean \pm SD & $13.7 \pm 1.12$ & $10.64 \pm 1.56$ & $10.78 \pm 1.39$ & \multirow{2}{*}{7.94} & $<0.006^{*}$ \\
& Range & $12.23-15.22$ & $8.99-12.83$ & $9.43-12.65$ & \\
\hline
\end{tabular}

Number of sacrificed rats for each group was 5 rats.

SD: Standard Deviation. $\quad *$ : Significant if $P \leq 0.05 \quad * *$ : highly significant $(P \leq 0.001)$.

Table 2: Statistical analysis of number of normal Purkinje cells in the different studied groups using One way ANOVA test.

\begin{tabular}{|c|c|c|c|c|c|c|}
\hline Postnatal day & Number of Purkinje cells & Group A & Group B & Group C & $\mathrm{F}$ & $\mathrm{P}$ \\
\hline PD 7 & $\begin{array}{c}\text { Mean } \pm \text { SD } \\
\text { Range }\end{array}$ & $\begin{array}{c}6.6 \pm 0.89 \\
6-8\end{array}$ & $\begin{array}{c}2.8 \pm 1.1 \\
2-4\end{array}$ & $\begin{array}{c}1.8 \pm 0.84 \\
1-3\end{array}$ & 35.63 & $<0.001^{* *}$ \\
\hline PD 14 & $\begin{array}{c}\text { Mean } \pm \mathrm{SD} \\
\text { Range }\end{array}$ & $\begin{array}{c}17.4 \pm 1.14 \\
16-19\end{array}$ & $\begin{array}{c}4 \pm 1.41 \\
3-6\end{array}$ & $\begin{array}{c}0.6 \pm 0.15 \\
0-1\end{array}$ & 328.72 & $<0.001^{* *}$ \\
\hline PD 21 & $\begin{array}{c}\text { Mean } \pm \text { SD } \\
\text { Range }\end{array}$ & $\begin{array}{c}9.2 \pm 1.3 \\
8-11\end{array}$ & $\begin{array}{c}3.6 \pm 0.55 \\
3-4\end{array}$ & $\begin{array}{c}0.6 \pm 0.19 \\
0-1\end{array}$ & 124.26 & $<0.001^{* *}$ \\
\hline
\end{tabular}

Number of sacrificed rats for each subgroup was 5 rats.

SD: Standard Deviation. $\quad *$ : Significant if $P \leq 0.05 \quad * *$ : highly significant $(P \leq 0.001)$. 
Table 3: Statistical analysis of area \% of bcl-2 immunoexpression in Purkinje cells in the different studied groups using one way ANOVA test.

\begin{tabular}{|c|c|c|c|c|c|c|}
\hline Postnatal day & Area $\%$ of bcl-2 immunoexpression & Group A & Group B & Group C & $\mathrm{F}$ & $\mathrm{P}$ \\
\hline PD 7 & $\begin{array}{c}\text { Mean } \pm \mathrm{SD} \\
\text { Range }\end{array}$ & $\begin{array}{l}2.51 \pm 0.33 \\
2.09-2.92\end{array}$ & $\begin{array}{l}3.96 \pm 0.82 \\
3.07-5.12\end{array}$ & $\begin{array}{c}12.84 \pm 3.76 \\
6.72-16\end{array}$ & 31.47 & $<0.001^{* *}$ \\
\hline PD 14 & $\begin{array}{c}\text { Mean } \pm \mathrm{SD} \\
\text { Range }\end{array}$ & $\begin{array}{c}2.59 \pm 1.2 \\
0.56-3.55\end{array}$ & $\begin{array}{l}4.94 \pm 1.16 \\
3.91-6.51\end{array}$ & $\begin{array}{c}14.89 \pm 2.85 \\
11.45-19.13\end{array}$ & 58.61 & $<0.001^{* *}$ \\
\hline PD 21 & $\begin{array}{c}\text { Mean } \pm \text { SD } \\
\text { Range }\end{array}$ & $\begin{array}{l}2.57 \pm 0.95 \\
1.01-3.55\end{array}$ & $\begin{array}{l}6.56 \pm 2.22 \\
4.52-9.77\end{array}$ & $\begin{array}{c}27.87 \pm 3.16 \\
24.55-31.29\end{array}$ & 175.75 & $<0.001^{* *}$ \\
\hline
\end{tabular}

Number of sacrificed rats for each group was 5 rats.

SD: Standard Deviation. * :Significant if $P \leq 0.05 * *$ : highly significant $(P \leq 0.001)$.

\section{DISCUSSION}

The ACR causes different kinds of neuropathy depending on the duration and concentration of exposure. Workers exposed to ACR develop central and/or peripheral nerve syndromes such as cerebellar ataxia and peripheral neuropathy ${ }^{[18]}$.

In the present study, severe neurological abnormalities in acrylamide treated pups $(10 \mathrm{mg} / \mathrm{kg})$ were detected especially, in group C. These neurological signs were explained by Lopachin et al. ${ }^{[20]}$ to be caused by distal axonopathy in the peripheral nervous system. Standring et $a l^{[21]}$ added that the Purkinje cell is the sole efferent source of the cerebellum and so, it plays an important role in the neurological defects such as muscle weakness and gait abnormalities.

Sorgel et al. ${ }^{[7]}$ found that ACR and their metabolites pass easily through the placenta due to their solubility in water and are distributed in many fetal tissues during gestation.

In the present study, by exposure of acrylamide, in all age subgroups of prenatal and perinatal groups B and C, there were variant changes occurred in depth and width of both folds and sulci when compared with control groups. In agreement, Allam et al. ${ }^{[12]}$ reported that the folds appeared deep at D7. Then, it became deeper at D14 \&D21 and the sulci were narrow in contrast to wide and crude sulci that appeared in acrylamide treated groups.

In this study, altered architecture of the cerebellar folds with the exposure of acrylamide was noted. In group B at PD7, the cerebellar folds showed cavitations within their matrix and detachment of their covering pial surface epithelium. While, in group $\mathrm{C}$, there were more complicated picture such as; presence of detachment and cracks through the fold layers, destruction of white matter core and accumulation of hemorrhage between the cerebellar folds. These findings were in agreement with a previous literature ${ }^{[12]}$. They detected the occurrence of the hemorrhage in acrylamide treated group and described it as a type of brain damage and attributed that to chronic acrylamide exposure. Also similar results observed by Shaheed et al. ${ }^{[22]}$ and Rawil et al. ${ }^{[23]}$ who demonstrated that ACR administration caused focal gliosis in the cerebral cortex and cerebrum, focal hemorrhage in the meninges and vacuolization in cerebral cortex, cerebrum, cerebellum and medulla oblongata.

At PD14, EGL was less thick than that of PD7 of the same normal group because of migration of their cells to the IGL. However, with exposure of acrylamide, the thickness of EGL covering surfaces of the cerebellar folds or lining the sulci was significantly decreased in group B. A highly significant decreased thickness of EGL was noted in group $\mathrm{C}$ when compared to the same control group. These findings were in agreement with the previous literatures reported by Allam et al. ${ }^{[12]}$ who found that the normal EGL was thick at D7 normal rats then started to decrease by D14 and became thin. Marcelo and Fahad ${ }^{[24]}$ added that EGL is the external germinal layer that generates the granular cells and then the cells start to migrate through the Purkinje cell layer at postnatal days 4 to form the IGL. Allam et al. ${ }^{[12]}$ also found that due to chronic pre- and postnatal acrylamide administration, EGL was thin at D7 and attributed this to the delay in the proliferations and differentiation of these cells of this layer. This confirmed by Fonnum and lock ${ }^{[25]}$ who documented that the Purkinje and granule cells are the most important targets in cerebellum for toxic substances.

In the current study, in the normal control group A, EGL was completely disappeared at D21. However, with exposure of acrylamide in group $\mathrm{C}$ of the same age, a single raw of EGL was still present covering some cerebellar folds. Allam et al. ${ }^{[12]}$ mentioned that this remained layer represented at D21 as one row of cells or was completely absent in some regions and disappeared completely at D28 in the normal rat and at D21 in the guinea pig ${ }^{[26]}$.

Sarana and Hawkes ${ }^{[27]}$ considered acrylamide as one of numbers of toxins that causing Purkinje cells death as phenytoin, lithium, phencyclidine, bismuth, nicotine, somatostatin and methotrexate.

In support with previous literatures, the present work also observed damage of Purkinje cells of the rat cerebellum when exposed to acrylamide in the prenatal and perinatal treated groups with different degree of distortion increasing with the increase of duration of exposure. Moreover, the number of normal Purkinje cells was highly significant decreased from group A to group $\mathrm{C}(P<0.001)$.

The different degree of distortion in Purkinje cells ranging from deep staining of its cytoplasm to loss of 
their dendrites and axons as demonstrated by microscopic examination of this study established the pathological consequences of acrylamide neurotoxicity ${ }^{[28,29]}$. They suggested that the shrinkage of the cells and deep staining of the cytoplasm are signs of neuronal cell death. Also the shrinkage and irregularity in shape of the Purkinje cells referred by Hirai et al. ${ }^{[30]}$ to disorganization of the cytoskeletal elements in the cell body and processes of the cell. Induction of free radicals and oxidative stress, by acrylamide causes membrane necrosis and mitochondrial dysfunction of Purkinje cells ${ }^{[22,28,31]}$.

In the present study, with exposure of acrylamide, the Purkinje cell layer was surrounded by wide pericellular spaces at D14 and 21 in prenatal treated group B. However, in perinatal treated group $C$, these peri-cellular spaces coalesced and became very wide one space leading to complete separation between the PCL from IGL. These findings were in agreement with El-Bakary and Mousa ${ }^{[28]}$ and Zhang et al. ${ }^{[32]}$. They found marked spongiosis and pericellular vacuolation surrounding the Purkinje cells of acrylamide-treated groups and attributed this to the shrinkage of Purkinje cells themselves leaving apparent pericellular spaces.

By Immunohistochemistry, the current study showed mild positive immunoreaction for bcl-2 in Purkinje cells in control group, moderate immunoreaction in prenatal group and intense immunoreactions in perinatal group. This finding was in agreement with $\mathrm{Li}$ et al. ${ }^{[18]}$ who postulated that expression of bcl-2 in the nervous system significantly changed after ACR administration. In the CNS, the expression of bcl-2 followed the same change; it decreased in the low dose group and increased in the high dose group.

In addition, the morphometric and statistical results of this work showed that the area \% of bcl-2 immunoexpression showed a high significant increase from group $\mathrm{B}$ to $\mathrm{C}$ when compared to control group $\mathrm{A}$ $(P<0.001)$. This finding was in agreement with Li et al. ${ }^{[18]}$ who found that the bcl-2 immunoreaction was highly significantly increased in the sciatic neurons in the low and the high dose of ACR toxicity than control group.

Moreover, Cui et al. ${ }^{[33]}$ found that concomitant decrease in the immunoexpression of bcl-2 with increase in bax immunoexpression is not the role in neuronal degeneration. They found that subchronic exposure to the neurotoxic anthexanedione resulted in significantly increased expression of both anti-apoptotic protein (Bcl-2), proapoptotic protein (Bax) and apoptotic marker (Caspase-3) in cerebral cortex and cerebellum. They added that these changes might be involved in early molecular regulatory mechanism of apoptosis.

Chen et al. ${ }^{[34]}$ found that the lower concentrations of toxins, particularly if delivered over a more protracted time course, induce apoptosis while higher levels induce necrosis. Moreover, intermediate concentrations of neurotoxicant often induce a mixture of necrosis and apoptosis.
From the current study, a higher expression of bcl-2 in acrylamide treated group was a part of normal protective defense mechanism against neuronal injury and damage by acrylamide. Chong et al..$^{[35]}$ and Doughty et al..$^{[36]}$ mentioned that regardless of the type of neuronal death induced, over-expression of anti-apoptotic Bcl-2 gene or bax gene (pro-apoptotic marker), disruption provides significant neuroprotection in several in vivo and in vitro disease degenerative models.

In the present work, the width, density and number of neurons in the normal molecular layer at D21, were higher than other ages of control groups. However, with exposure of acrylamide in prenatal and perinatal groups B,C, the molecular layer showed variant width, appeared hazy, edematous with loss of dendritic arborizations of $\mathrm{PC}$ and contained vacuolated matrix and some vacuolated cells giving it a spongiform appearance. These findings were in agreement with Rawil et al. ${ }^{[23]}$ who mentioned that ACR administration caused varying histopathological changes and vacuolization in cerebral cortex, cerebellum and medulla oblongata.

The varying width of the ML of this work due to loss of dendritic arborizations was in accordance with previous literatures ${ }^{[37]}$. They reported that ML width is depending on the number of its neurons and size of Purkinje cell arborizations. In addition, Shaheed et al. ${ }^{[22]}$ recorded that acrylamide mediates cell loss, especially Purkinje cells and malnutrition induces aberration in Purkinje cells dendrites.

In the present work, in the normal group, IGL became thicker started to be differentiated at D14 and completely differentiated from the white matter core at D21. They packed with high population of scattered deeply stained granule cells. This also clarified by Galas et al. ${ }^{[38]}$. They mentioned that by the third postnatal week the EGL disappears and IGL becomes the granular layer (GL) after completion of cerebellar development. Also Yacubova and Komuro $^{[39]}$ explained that many factors such as activity of Calcium channels, N-methyl-D-aspartate (NMDA) type of glutamate receptors and intracellular Calcium fluctuations controlling granule cell migration from EGL to IGL. Also, Bahgat et al. ${ }^{[37]}$ described that the granule cells were high in number, rounded in shape and occupied the deep region of IGL and were most often formed after birth.

However, with exposure of acrylamide in prenatal and perinatal groups B,C, IGL showed large vacuolations and degenerated granule cells were clumped in groups and enclosing edematous congested spaces. In some areas, the IGL increased in width and thickness (if compared with control group) and showed obvious herniation. This was in agreement with Tanaka and Okeda ${ }^{[40]}$ who noted that oral administration of ACR produced selective granule cells destruction in the granular layer of the cerebellar cortex together with neurological signs such as ataxia, convulsion and delayed righting reflex. The authors also added that it caused multifocal destruction of granule cell with nuclear pyknosis and spongiosis of the neurophile in the granular layer. 
The role of ACR in occurrence of apoptosis in several brain regions including cerebellum was explained by Bordini et al. ${ }^{[41]}$, Barber and LoPachin ${ }^{[42]}$ and LoPachin and Barber ${ }^{[43]}$ who found that ACR selectively reacts with glutathione (GSH) adducts. The formation of this adduct in nervous tissue might impair the glucose metabolism. This impairment activates cytochrome c and apoptosis in early stages of ACR administration. These data were confirmed by Vaughn and Deshmukh ${ }^{[44]}$ who stated that neurons use glucose extensively and they show an increased regulation of the apoptotic pathway which allows for their long term survival. Neurons strictly inhibit cytochrome c mediated apoptosis by a mechanism dependent on glucose metabolism. This occurs through generation of intracellular glutathione (GSH) by the pentose phosphate pathway.

On the other hand, there are three hypotheses on the mechanism of ACR neurotoxicity: (1) inhibition of kinesinbased fast axonal transport, (2) alteration of neurotransmitter levels, and (3) direct inhibition of neurotransmission ${ }^{[45,46]}$. Other study detected that ACR subacute exposure reduced the concentration of the excitatory neurotransmitter glutamate in the CNS and may be one of the mechanisms that lead to ACR neurotoxicity ${ }^{[4]}$.

Recently, Zhang et al. ${ }^{[32]}$ showed that subacute exposure to ACR included structural damage of the cerebral cortex and cerebellum through the reduction in the protein expression of synapsin I and P- synapsin I. This reduction might lead to changes in synaptic vesicles distribution through the pre-synaptic areas. Therefore, this leads to a reduction in the excitatory neurotransmitter glutamate release in the rat CNS, and in turn induces abnormal neurobehavior. The functional damage of synaptic vesicles may thus be a mechanism explains ACR neurotoxicity.

\section{CONCLUSION}

Acrylamide adversely affected the structure of the developing cerebellum of male albino rat offspring after exposure to it during the gestation and lactation periods. The severity of these changes was increased with longer period of exposure. Further measures should be needed to minimize acrylamide formation in food.

\section{CONFLICTS OF INTERESTS}

There are no Conflicts of Interests.

\section{REFERENCES}

1. Friedman M. Chemistry, biochemistry and safety of acrylamide: a review. Journal of Agriculture and Food Chemistry 2003; 51: 4504-4526.

2. Lopachin RM, Ross JF, Lehningm EJ. Nerve terminals as the primary site of acrylamide action. A hypothesis Neurotoxicology 2002a; 23(1): 43-59.

3. Zhang Y, Zhang Y. Study on reduction of acrylamide in fried bread sticks by addition of antioxidant bamboo leaves and extract of green tea. Asia Pac J. Clin. Nutr. 2007; 16: 131-136.
4. Alberts B, Johnson A, Lewis J, Raff, M, Roberts K, Walter P. Molecular Biology of the Cell, $4^{\text {th }}$ Edition, Routledge, March, ISBN 2002; 0-8153-3218-1.

5. Hagmar, L, Wirfält, E, Paulsson, B., \& Törnqvist, M. Differences in hemoglobin adduct levels of acrylamide in the general population with respect to dietary intake, smoking habits and gender. Mutation Research, 2005; 580(1-2), 157-165. https://doi.org/10.1016/j. mrgentox.2004.11.008

6. Garey J, Sherry AF, Merle GP. Developmental and behavioral effects of acrylamide in Fischer 344 rats. Neurotoxicol. and Teratol. 2005; 27 (4): 553-563.

7. Sorgel F, Weissenbacher R, Kinzig-Schippers M, Hofmann A, Illauer M, Skott A, Landersdorfer C. Acrylamide increased concentrations in homemade food and first evidence of its variable absorption from food, variable metabolism and placental and breast milk transfer in humans. Chemotherapy 2002; 48 : 267-274.

8. LoPachin, R.M.: Changing view of acrylamide neurotoxicity. Neurotoxicology; 2004; 25: 617-630.

9. LoPachin, RM., Balaban, CD, Ross, JF. Acrylamide axonopathy revisited. Toxicol. Appl. Pharmacol. 2003; 188 (3), 135-153.

10. Lehning EJ, Balaban CD., Ross JF, Reid MA, Lopachin RM. Acrylamide neuropathy I: Spatiotemporal characteristics of nerve cell damage in rat cerebellum. Neurotoxicology 2002a; 23(3): 397-414.

11. Lehning EJ, Balaban CD, Ross JF, Lopachin RM. Acrylamide neuropathy II Spatiotemporal characteristics of nerve cell damage in rat brainstem and spinal cord. NeuroToxicology 2002b; 23:415-429.

12. Allam A, El-Ghareeb A, Abdul-Hamid M, Baikry A, Sabri MI. Prenatal and perinatal acrylamide disrupts the development of cerebellum in rat: Biochemical and morphological studies. Toxicol. Ind. Health 2011; 27(4): 291-306.

13. Allam AA, Abdul-Hamid M, Bakry A, El-Ghareeb A, Ajarem JS, Sabri M. Effect of Acrylamide on Cerebral Neurons Development in Albino Rat. Life Science Journal 2013;10(3):1814-1825.

14. Tyla RW, Friedman MA, Losco PE, Fisher LC, Johnson KA, Strother DE, Wolf CH. Rat twogeneration reproduction and dominant lethal study of acrylamide in drinking water. Reproductive Toxicology 2000; 14: Sep-Oct;14(5):385-401.

15. Institute Of Laboratory Animal Resources, Commission on Life Science, National Research Council of national academies. Guide for the Care and Use of Laboratory Animals. National Academy press, Washington, D.C, 8th Ed. 2011; :11-55.

16. Bancroft JD, Gamble A. Theory and practice of histological techniques. 6th edition, Churchill Livingstone, New York, London, 2008; pp: 165-175. 
17. Kiernan J. Histological and Histochemical Method Theory and Practice. 3rd ed. Oxford, Boston, Johannesburg and New Delhi, 2000.

18. Li SX, Cui N, Zhang CL, Zhaoc XL, Yu SF, Xie KQ. Effect of subchronic exposure to acrylamide induced on the expression of bcl-2, bax and caspase- 3 in the rat nervous system. Toxicology 2006; 217:46-53.

19. Dean AG, Arner TG, Sunki G, Sangam S, Friedman $\mathrm{R}$, Lantinga $\mathrm{M}$, and Diskalkar S. Epi-info version 1 for the year 2000. A Database and Statistics Program for Public Health Professionals CDC. Georgia, USA, $2000: 1-191$

20. Lopachin RM, Ross JF, Reid ML, Das S, Mansukhani S, Lehning EJ. Neurological evaluation of toxic axonopathies in rats: Acrylamide and 2,5-hexanedione. Neuro Toxicology 2002b; 23:95-110.

21. Standring S, Borley NR, Collins P, Crossman AR, Gatzoulis MA, Healy JC, Johnson D, Mahadevan V, Newell RLM and Wigley CB. Gray's Anatomy: The Anatomical Basis of Clinical Practice. $40^{\text {th }}$ Edition, Churchill Livingstone. London, Tokyo, 2008, pp: 331-349.

22. Shaheed IB, Kawkab AA, Makhlouf MM. Toxicological and pathological studies on acrylamide neurotoxicity in albino rats. Egyptian Journal of Comparative Pathology and Clinical Pathology 2006; 19: 63-82.

23. Rawil SM, Marie MS, Sohair R, Fahmy SR, El-Abied. Hazardous effects of acrylamide on immature male and female rats. Khalius King Abdul Aziz University. African Journal of Pharmacy and Pharmacology 2012; 6 (18): 1367-1386.

24. Marcelo RSV and Fahad S. The cerebellum at birth in therian mammals, with special reference to rodents. Brain Behavior 2002; 59: 101-113.

25. Fonnum $\mathrm{F}$ and lock E.A. cerebellum as a target for toxic substances 2000; toxicology letters vol.112-113 P.9-16

26. Dalia M.S. Comparative studies on the ontogeny of sensorimotor reflexes and locomotive activity in small mammals and their applications on infants. $\mathrm{PhD}$ Thesis, Fac of Science, Mansour Univ, Egypt, 2002.

27. Sarana JR and Hawkes R. Patterned purkinje cell death in the cerebellum . progress in neurobiololgy 2003;70(6):473-507.

28. El-Bakary $\mathrm{Na}$ and Mousa Am. Light and electron microscopic study on the effect of acrylamide on the cerebellar cortex of adult albino rat and the possible protective role of vitamin B6. Egyptian Journal of Histology 2006; 29 (2): 179-192.

29. Al-Haiyani AA, Hamdy RM, Abdel-Raheem HN. Study of the Effect of Acrylamide on Purkinje Cells of the Cerebellum in Albino Rats. Suez Canal Univ. Med. J. $2010 ; 12(2): 35-42$.

30. Hirai U, Hartmann E, Angerer J. Acrylamide in children: Exposure assessment via urinary acrylamide metabolites as biomarkers. International Journal of Hygiene and Enviro-nmental Health 2009; 212(2):135-141.

31. Yousef MI, El-Demerdash FM. Acrylamide-induced oxidative stress and biochemical perturbations in rats. Toxicology 2006; 219: 133-141.

32. Zhang B, Shao H, Wang Xh, Chen X, Li Z, Cao P, Zhu D, Yang Yg, Xiao Jw And Li B. Acrylamide- induced Subacute Neurotoxic Effects on the Cerebral Cortex and Cerebellum at the Synapse Level in Rats. Biomed Environ Sci,; 30(6): 2017; 432-443.

33. Cui N., Li S., Zhao X., Zhang C. Yu L, Zhu Z, Xie $\mathrm{K}$. Expression of Bcl-2 , Bax and Caspase-3 in nerve tissues of rats chronically exposed to 2,5 -hexanedione. Neurochemical Research 2007; 32(9):1566-1572.

34. Chen Z, Chen X, Chen H, Chen HS, Zhou, T, Lu HS. Schwann cell apoptosis in wallerian degenerated sciatic nerve of the rat. Chin. J. Traumatol. 2004; 7 (4):220-228.

35. Chong MJ, Murray MR, Gosink EC, Russell HRC, Srinivasan A, Kapsetaki M, Korsmeyer SJ, McKinnon PJ. Atm and Bax cooperate in ionizing radiationinduced apoptosis in the central nervous system. Proc. Natl. Acad. Sci. U. S. A. 2000; 97: 889-894.

36. Doughty ML, De-Jager PL, Korsmeyer SJ Heintz N. Neurodegeneration in Lurchermice occurs via multiple cell death pathways. J. Neurosci. 2000; 20 pp. 3687-3694.

37. Bahgat M, Abdul-Hamid M, Allam AA. Effect of ethanol ingestion on the development of cerebellar cortex neurons in albino rat. Journal of Egyptian German Society of Zoology 2006; 50C: 137-159.

38. Galas L, Bénard M, Lebon A, Komuro Y, Schapman D, Vaudry H, Vaudry D, Komuro H. Postnatal migration of cerebellar interneurons Brain sci. 2017;7(62):1-18. DOI:10.3390/brainsci7060062

39. Yacubova E. and Komuro H. cellular and molecular mechanisms of cerebellar granule cell migration. Cell Biochem. Biophs. 2003; 37(3) 213-234.

40. Tanaka G, Okeda R. N-[4-(3- Ethoxy-2 hydropropoxy) phenyl] acrylamide selectively induces apoptosis of cerebellar granule cells in vivo and invitro in rats. Acta Neuropathologica 2000; 99(4):337-344.

41. Bordini E, Hamdan M, Righetti PG. probing acrylamide alkylation sites in cysteine -free proteins by matrix -assisted laser desorption/ ionisation time of flight. Rapid comm. Mass Spec. 2000; 14:840 848. 
42. Barber DS, Lopachin RM. Proteomic analysis of acrylamide protein adduct formation in rat brain synaptosomes. Toxicol. Appl. Pharmacol. 2004; 201:120-136.

43. Lopachin RM, Barber DS. Synaptic cystein sulfhydryl groups as targets of electrophilic neurotoxicants. Tox. Sci. 2006; 94:240-255.

44. Vaughn AE and Deshmukh M. Glucose metabolism inhibits apoptosis in neurons and cancer cells by redox inactivation of cytochrome c. Nature cell Biology 2008; 10:1477-1483.
45. Erkekoglu P. and Baydar T. Acrylamide neurotoxicity. Nutritional neuroscience 2014; 17(2): 49-57. https://doi.org/10.1179/1476830513Y.0000000065

46. Lopachin RM, Gavin T. Acrylamide-induced nerve terminal damage: relevance to neurotoxic and neurodegenerative mechanisms. J. Agric Food Chem. 2008; 56, 5994-6003.

47. Zhang B, Hua S, Wang XH, Xiao C, LI ZS, Peng C, Dan Z, Yang YG, Xiao JW, Bin L. 2017. Acrylamideinduced subacute neurotoxic effects on the cerebral cortex and cerebellum at the synapse level in rats. Biomedical and Environmental Sciences 30:432-443. 
الملخص العربى

\title{
تأثير الأكريلاميد علي نمو المخيخ في الجرذ الأبيض
}

\author{
وسام السيد أمين، أشرف صابر حجاب، أمل الشحات إبراهيم، حنان السبد لطقي مختار \\ قسم التشريح الآدمي والأجنة ـ كلية الطبـ جامعة الزقازيق
}

المقدمة: الأكريلاميد هو مادة سامة للحيو انات و البشر. الهدف : توضيح التغيرات التركيبية المحتملة التي قد تحدث اثناء نمو المخيخ لسلالة الذكور من الجرذان البيضاء بعد اعطاء أمهاتهم جر عة من الأكريلاميد عن طريق الفم خلال فترة الحمل وحتى الفطام. المواد و الطـرق المستخدمة: بعد التزاوج, قسمت أربعة وخمسون من إناث الجرذان البيضاء الحوامل الى ثلاث مجمو عات بالتساوى بحيث ان: المجموعة الاولى: لم تتلق أي مادة و أعتبرت مجمو عة ضابطة، المجموعة الثانية: ثم إعطائها • ( ملجم \كجم \يوميا من مادة الأكريلاميد بالفم من اليوم السابع حتي الولادة و المجمو عة الثالثة: تم إعطائها نفس الجر عة من مادة الأكريلاميد و الطريقه من اليوم السابع حتى اليوم الواحد و العثرين بعد الولادة.

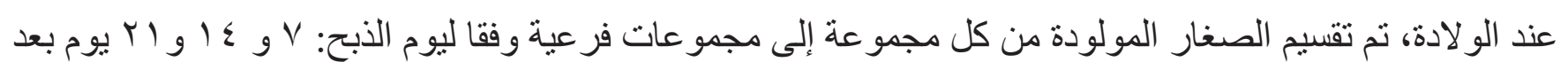
الو لادة على الترتيب، و تمت معالجه عينات المخيخ للفحص المجهري الضوئي، الدراسة الهستوكيميائية المناعية، الدر اسة المورفومترية و الدر اسة الإحصائية. النتائج: لقد كثفت الملاحظة العامة للجرذان في المجموعات التي عولجت بالأكريلاميد عن وجود علامات لتشوهات عصبية. وقد وجدت تغيير ات تنكسية في بنية الأنسجة للمخيخ في كل المجموعات المعالجة. ولوحظ ان هذه التغييرات

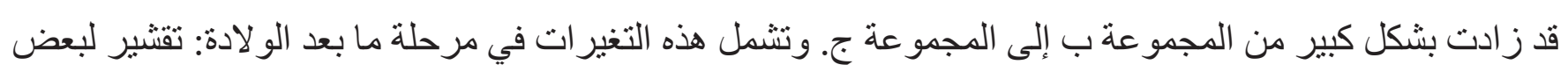
الاغشية السحائية المغلفة للطيات، وجود تجاويف وشقوق داخل الطيات مع تر اكم النزيف بينها، لوحظ تغير ات متدهورة لجميع الطبقات الحبييية وتلف شديد لخلايا بيركنجي. ومن خلال النتائج المورفومترية والإحصائية، أظهر التحليل الإحصائي نقص ذو دلالة إحصائية عالية لمتوسط قيمة سمك الطبقة الحبيية الخارجية ومتوسط قيمة عدد خلايا بيركنجي في كل من المجموعة (ب و ج) إذا ما قورنت بالمجموعة الضابطة الطبيعية (أ). بينما أظهرت النسبة المئوية للمساحة المعبرة عن صبغه مادة (بي سي لـبلَ) (Bcl-2) زيادة ذو دلالة إحصائية عالية معتد بها. الخلاصة: أثرت مادة الأكريلاميد سلبًا على بنية المخيخ النامي لذرية الجرذان البيضاء التي تعرضت لهاء لها أثناء فترات الحمل و الرضاعة. وز ادت شدة هذه التغيير ات مع الفترات الأطول من التعرض. يجب أن تكون هناك حاجة إلى مزيد من التدابير لتقليل تكوين مادة الأكريلاميد في الغذاء. 